\title{
Aansluiting Technisch Onderwijs en de Arbeidsmarkt
}

Citation for published version (APA):

Fouarge, D., Bakens, J., \& Bijlsma, I. (2018). Aansluiting Technisch Onderwijs en de Arbeidsmarkt. ROA. ROA Technical Reports No. 006 https://doi.org/10.26481/umarot.2018006

Document status and date:

Published: 01/01/2018

DOI:

10.26481/umarot.2018006

Document Version:

Publisher's PDF, also known as Version of record

\section{Please check the document version of this publication:}

- A submitted manuscript is the version of the article upon submission and before peer-review. There can be important differences between the submitted version and the official published version of record.

People interested in the research are advised to contact the author for the final version of the publication, or visit the DOI to the publisher's website.

- The final author version and the galley proof are versions of the publication after peer review.

- The final published version features the final layout of the paper including the volume, issue and page numbers.

Link to publication

\footnotetext{
General rights rights.

- You may freely distribute the URL identifying the publication in the public portal. please follow below link for the End User Agreement:

www.umlib.nl/taverne-license

Take down policy

If you believe that this document breaches copyright please contact us at:

repository@maastrichtuniversity.nl

providing details and we will investigate your claim.
}

Copyright and moral rights for the publications made accessible in the public portal are retained by the authors and/or other copyright owners and it is a condition of accessing publications that users recognise and abide by the legal requirements associated with these

- Users may download and print one copy of any publication from the public portal for the purpose of private study or research.

- You may not further distribute the material or use it for any profit-making activity or commercial gain

If the publication is distributed under the terms of Article $25 \mathrm{fa}$ of the Dutch Copyright Act, indicated by the "Taverne" license above, 


\section{Maastricht University $\$ \mathrm{ROA}$}

\section{Aansluiting Technisch Onderwijs en de Arbeidsmarkt}

Didier Fouarge

Jessie Bakens

Ineke Bijlsma

\section{ROA Technical Report}

ROA-TR-2018/6

Researchcentrum voor Onderwijs en Arbeidsmarkt | ROA

Research Centre for Education and the Labour Market / ROA 


\title{
Aansluiting Technisch Onderwijs en de Arbeidsmarkt
}

\author{
Didier Fouarge \\ Jessie Bakens \\ Ineke Bijlsma
}

ROA-TR-2018/6

September 2018

Research Centre for Education and the Labour Market Maastricht University

P.O. Box 616, 6200 MD Maastricht, The Netherlands

$\mathrm{T}+31433883647 \mathrm{~F}+31433884914$

secretary-roa-sbe@maastrichtuniversity.nl

www.roa.nl 


\section{Inhoud}

Inhoud 1

1 Introductie 2

2 Verdeling gediplomeerden over beroepen 5

2.1 Recent gediplomeerden 6

2.2 Werkzame beroepsbevolking 9

3 Kenmerken van technici in niet-technische beroepen 11

3.1 Arbeidsmarktkenmerken van technisch gediplomeerden, naar

3.2 Gediplomeerden werkzaam buiten hun beroependomein 13

3.3 Meest voorkomende beroepen van technisch gediplomeerden 14

4 Subjectieve aansluiting onderwijs-arbeidsmarkt $\quad 17$

4.1 Verdeling subjectieve aansluiting over opleidingen en beroepen $\quad 17$

4.2 Samenhang tussen subjectieve aansluiting en opleiding 18

5 Lonen 20

5.1 Uurloon van recent gediplomeerde technici 20

5.2 Uurloon van technici op de arbeidsmarkt 24

6 Andere studies $\quad 25$

7 Conclusie $\quad 27$

8 Verwijzingen 29

Bijlage I ROA beroepenclassificatie $\quad 30$

Bijlage II ROA opleidingsclassificatie $\quad 35$ 


\section{Introductie}

$\mathrm{Er}$ is een grote vraag naar gediplomeerden met een technische achtergrond op de arbeidsmarkt. ROA becijfert dat er de komende 6 jaar bijna 340.000 baanopeningen zijn voor technische en ICT-beroepen (ROA 2017a). Gezien de instroom van schoolverlaters met een technisch diploma naar verwachting zal groeien, maar nog onvoldoende hoog is, wordt het voor werkgevers steeds moeilijker om voldoende technisch personeel te vinden. ROA verwacht dat werkgevers de komende 6 jaar voor $87 \%$ van hun vraag naar ICT-beroepen, en $66 \%$ van hun vraag naar technische beroepen te maken krijgt met grote knelpunten.

Uit verschillende onderzoeken blijkt bovendien dat schoolverlaters met een technische achtergrond niet alleen in technische of ICT-beroepen terecht komen, maar ook vaak werkzaam zijn in andere beroepen (SEO 2015, ROA 2017b). Door de frictie tussen vraag en aanbod van technisch personeel op de arbeidsmarkt, is het belangrijk om meer inzicht te verkrijgen in de mate waarin technisch personeel werkzaam is in andere, niet-technische beroepen.

De brede verspreiding van technici over verschillende sectoren en beroepen op de arbeidsmarkt kan een viertal oorzaken hebben.

1. Het uitspreiden van technisch personeel naar niet-technische beroepen kan het gevolg zijn van een veranderende inhoud van werk (Van den Berg et al. 2018). Het vermoeden speelt dat er steeds meer technische kennis nodig is in beroepen die niet standaard als technisch worden beschouwd (Fouarge 2017). Het zou dan ook zo kunnen zijn dat technisch geschoolden in een niettechnisch beroep werkzaam zijn volgens de ROA/CBS (2015) beroepenclassificatie, maar dat de technici zelf aangeven wel in het domein werkzaam te zijn, of zelf aangeven dat hun beroep wel technisch is.

2. Er kan sprake zijn van een slechte aansluiting van technisch onderwijs op de vraag vanuit de arbeidsmarkt. Gezien de verwachte groei in de techniek en ICT en het tekort aan personeel, en het belang van deze sectoren voor de economische groei van de Nederlandse economie, is het belangrijk dat gediplomeerden de juiste vaardigheden en kennis hebben om aan de slag te kunnen in de techniek en ICT.

3. Afgestudeerden met een ICT- en techniekachtergrond kunnen zelf kiezen voor een beroep in een ander domein omdat de studie is tegengevallen of het werken in technische of ICT-beroepen tegen valt. Eerder onderzoek laat zien dat er voor technisch geschoolden aantrekkelijke alternatieven zijn buiten de technische sector, of dat het werken in de technische sector voor sommige doelgroepen (zoals vrouwen) onaantrekkelijk is (SEO 2015). 
4. Daarnaast kan de classificatie van technische opleidingen ook opleidingen bevatten die minder 'hard' of 'exact' zijn waardoor de gediplomeerden van deze opleidingen niet terecht komen in technische beroepen (ROA 2017a).

Dit rapport focust zich op de eerste 3 genoemde oorzaken. In dit rapport wordt data gepresenteerd om meer inzicht te krijgen in de omvang van technisch geschoold personeel dat in een niet-technisch beroep werkt. Daarnaast wordt data gepresenteerd die inzicht kan verschaffen in de factoren die een mogelijke rol spelen bij dit fenomeen, zoals de veranderende inhoud van werk waardoor er steeds meer technisch personeel nodig is voor niet-technische beroepen (Fouarge 2017), de aansluiting tussen het techniekonderwijs en de arbeidsmarkt, en de kenmerken van technische en niet-technische beroepen. Dit resulteert in een overzicht van de omvang van het probleem van de aansluiting van technisch onderwijs en de arbeidsmarkt, en de baankenmerken die hierbij voorkomen.

Uit de gepresenteerde cijfers kunnen geen conclusies getrokken worden over de afweging die technisch geschoolden maken bij het kiezen van een baan, c.q., of de gepresenteerde kenmerken van banen doorslaggevend zijn voor de beroepskeuze van technici. Hiervoor is vervolgonderzoek nodig. In de conclusie van deze rapportage worden aanbevelingen gedaan voor de invulling van dit vervolgonderzoek, en in hoofdstuk 6 worden de inzichten uit deze rapportage gekoppeld aan ander ROA-onderzoek naar de technieksector.

De data in dit rapport is afkomstig uit drie verschillende bronnen: 1) de enquête beroepsbevolking (EBB), 2) het SchoolverlatersInformatieSysteem (SIS), en 3) de nationale alumni-enquête (NAE). Deze drie bronnen zijn gebruikt om data over verschillende facetten van de aansluiting onderwijs-arbeidsmarkt te kunnen meten. Bij het interpreteren van de data is het belangrijk om te weten uit welke bron de data afkomstig is, omdat niet alle data representatief is voor alle werkenden in Nederland. De EBB is een steekproef van de beroepsbevolking in Nederland en is zodoende representatief voor de gehele beroepsbevolking. Het SIS en de NAE zijn onderzoeken waarin gediplomeerden 1,5 jaar na het behalen van hun diploma worden geënquêteerd. Zodoende is de data uit deze bronnen representatief voor werkenden die zich nog maar kort op de arbeidsmarkt begeven. Dit heeft onder andere invloed op de hoogte van het gerapporteerde gemiddelde uurloon.

Eerder heeft ROA gepubliceerd over het stijgend percentage techniek gediplomeerden uit het mbo en hbo dat niet werkzaam is in een technisch beroep (ROA, 2017b). Vooral op mbo 4 daalt het percentage technisch gediplomeerden in technische of ICT-beroepen. Dit rapport biedt een verdieping van de daar gepresenteerde analyses, waarbij aangesloten wordt bij de in het Techniekpact gebruikte definities voor technische beroepen en opleidingen. Volgens de website van het Techniekpact wordt een brede definitie van techniek gebruikt om aan te sluiten bij de reikwijdte van het Masterplan Bèta en Technologie: "Het Masterplan duidt technici als mensen die één of meerdere technieken "praktisch" of reëel gebruiken. Zij werken bijvoorbeeld als laborant, onderzoeker, instrumentenmaker, 
ICT-er, werkvoorbereider, industrieel (creatief) ontwerper, loodgieter, ingenieur, operator of analist. Zij hebben de technische kennis om apparaten te bouwen en installaties te onderhouden. Zij houden technische systemen draaiende en ontwikkelen en implementeren nieuwe technologieën. Zij zoeken naar nieuwe wetenschappelijke kennis. Zij kunnen combinaties maken tussen disciplines (bètabèta en bèta-gamma) en kennis en technologie vertalen naar zinvolle innovaties op uiteenlopende terreinen, zoals zorg, voeding, energie en ICT." (https://www.techniekpact.nl/nationaal-techniekpact-2020)

Bij de meeste analyses wordt het aantal observaties vermeld. Resultaten die gebaseerd zijn op een klein aantal observaties zijn minder betrouwbaar. Voor enkele analyses is het niet mogelijk om de beroepen- of opleidingsindeling van het Techniekpact te gebruiken. In deze gevallen is de standaard ROA-indeling gebruikt en wordt dit aangegeven in de grafieken en tabellen. In Bijlage I en II staat de beroepen- en opleidingsclassificatie van ROA. De opleidings- en beroepenclassificatie van het Techniekpact is breder dan de ROA-indeling voor technische opleidingen en technische beroepen. Daardoor worden in het Techniekpact iets meer beroepen en opleidingen tot technische opleidingen en beroepen gerekend dan in de ROA-indeling het geval is. 


\section{Verdeling gediplomeerden over beroepen}

In dit hoofdstuk wordt de verdeling van gediplomeerden over verschillende beroepen in de techniek en buiten de techniek weergegeven voor 2006 en 2016 . Hierbij wordt onderscheid gemaakt naar het opleidingsniveau en naar technisch geschoolden en niet-technisch geschoolden. Ook wordt duidelijk gemaakt in welke mate het aandeel technisch geschoolden in technische beroepen toe- of afgenomen is tussen 2006 en 2016. De figuren gebaseerd op de SIS-data zijn toegespitst op de verdeling van recent afgestudeerden op de arbeidsmarkt. De figuren gebaseerd op de EBB-data gelden voor alle werkenden. Voor de EBB-data is de beroepenindeling van het Techniekpact gebruikt, maar is de ROA-definitie gehanteerd voor het selecteren van de technisch en niet-technisch gediplomeerden.

\section{Bevindingen:}

- Recent afgestudeerden met een niet-technische achtergrond hebben zelden een technisch beroep.

- Van de recent afgestudeerde mbo-technici werkt meer dan de helft in een technisch beroep.

- Van de recent afgestudeerde technici met een bèta natuur\&techniekopleiding (hbo en wo) werkt ruim tweederde wel in een technisch beroep.

- Van de werkende beroepsbevolking met een technische achtergrond werkt meer dan de helft in een niet-technisch beroep. 


\subsection{Recent gediplomeerden}

Figuur 2.1 percentage recent gediplomeerden op mbo2-niveau naar beroep

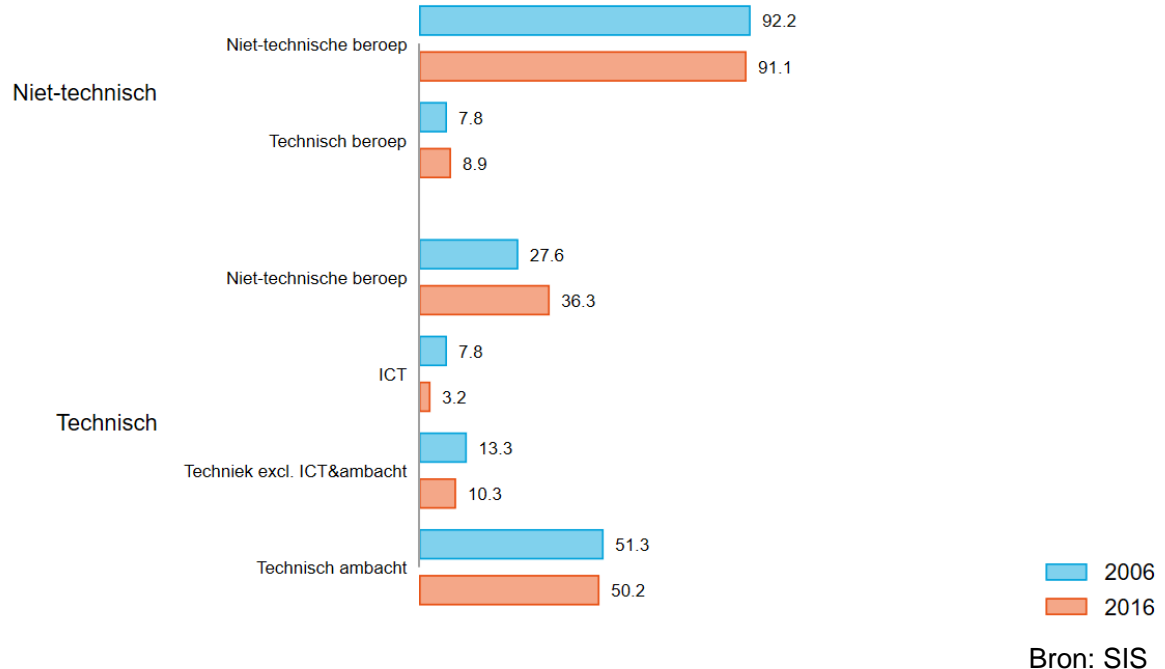

- Geen statistisch significante veranderingen tussen 2006 en 2016 in het aandeel technisch geschoolden in niet-technische beroepen op mbo2niveau.

Figuur 2.2 percentage recent gediplomeerden op mbo3-niveau naar beroep

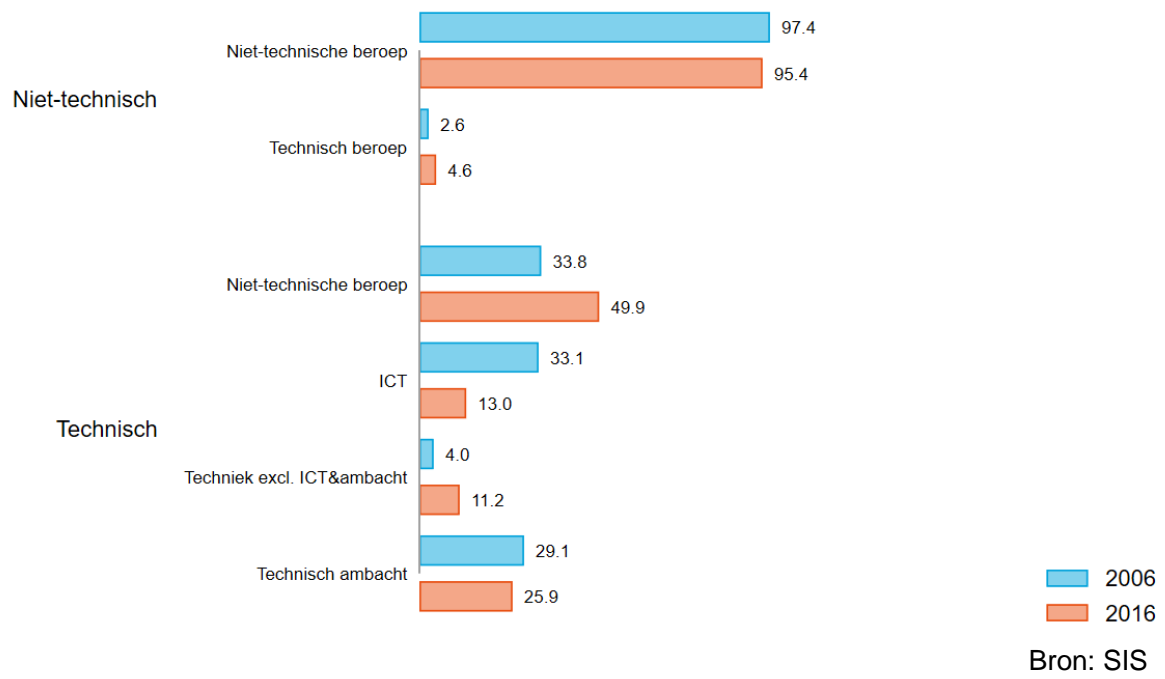

- Statistisch significante toename tussen 2006 en 2016 in het aandeel technisch geschoolden in niet-technische beroepen op mbo3-niveau. 
Figuur 2.3 percentage recent gediplomeerden op mbo4-niveau naar beroep

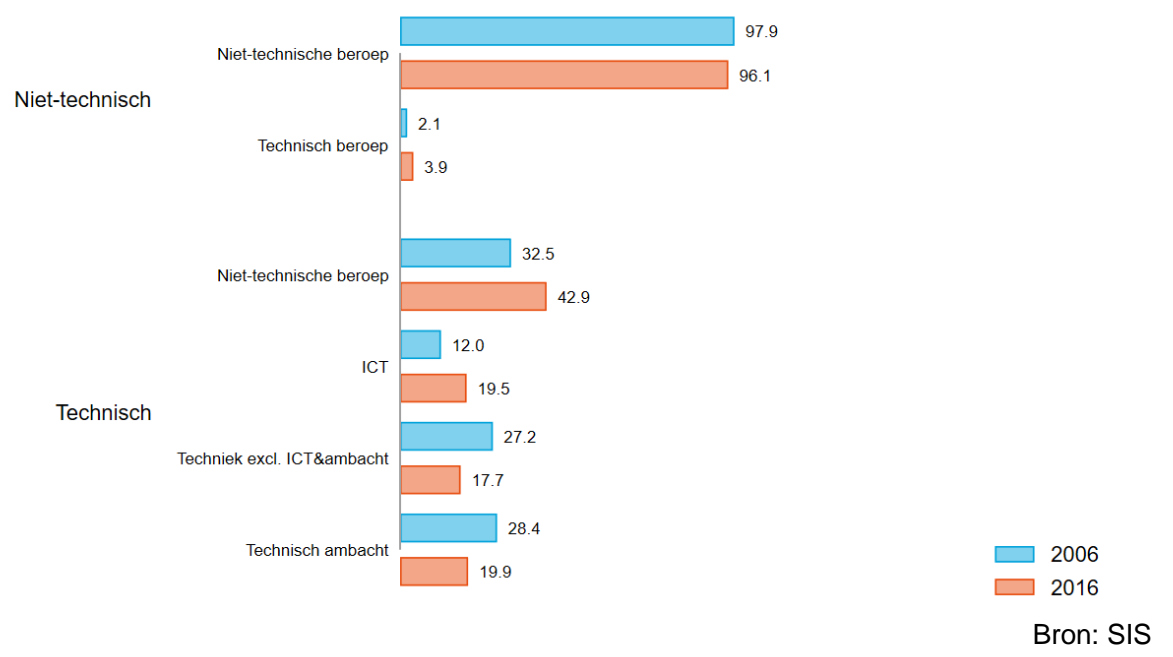

- $\quad$ Statistisch significante toename tussen 2006 en 2016 in het aandeel technisch geschoolden in niet-technische beroepen op mbo4-niveau.

Figuur 2.4 percentage recent gediplomeerden op hbo-niveau naar beroep*

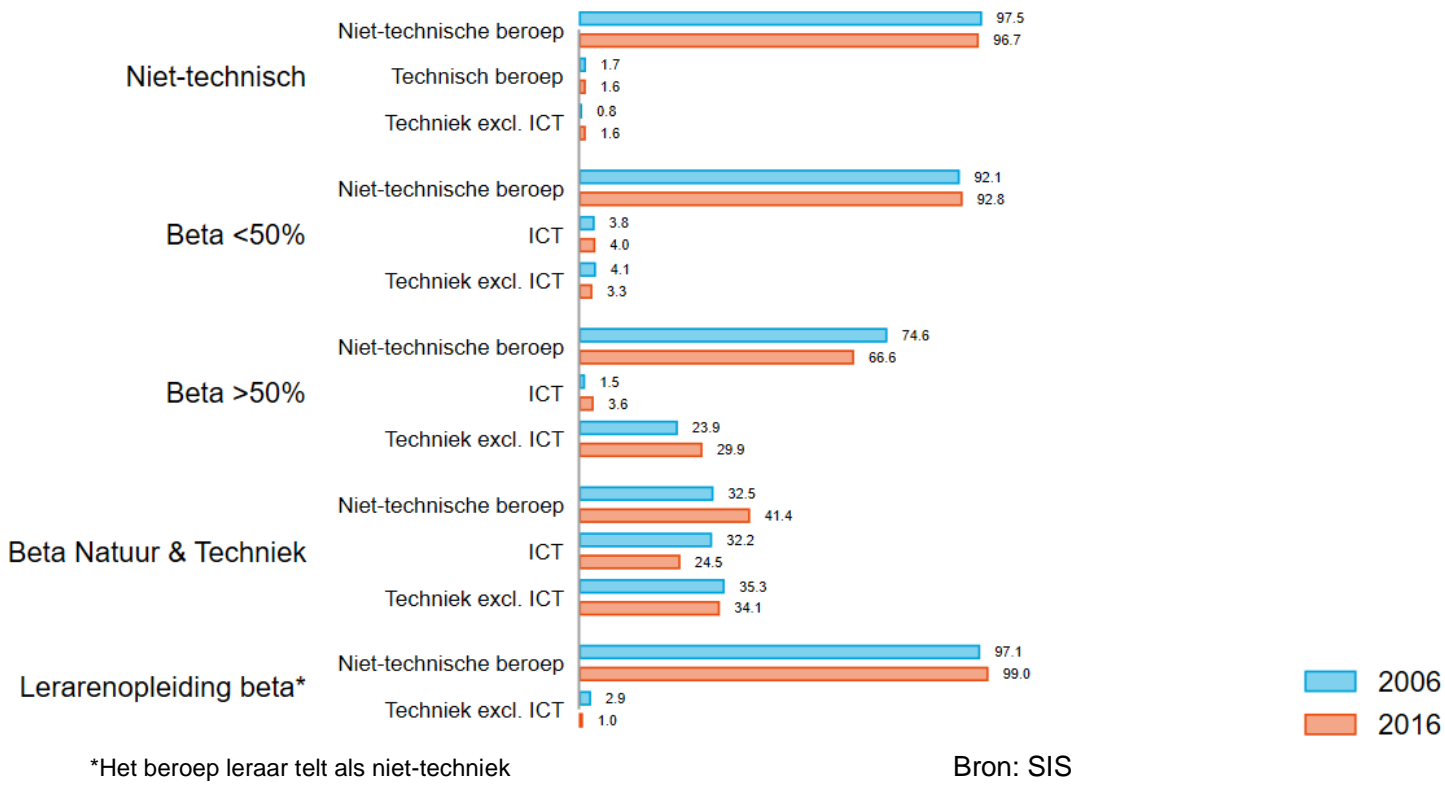

- $\quad$ Statistisch significante toename tussen 2006 en 2016 in het aandeel bèta natuur\&techniek geschoolden in niet-technische beroepen op hbo-niveau. 
Figuur 2.5 percentage recent gediplomeerden op wo niveau naar beroep*

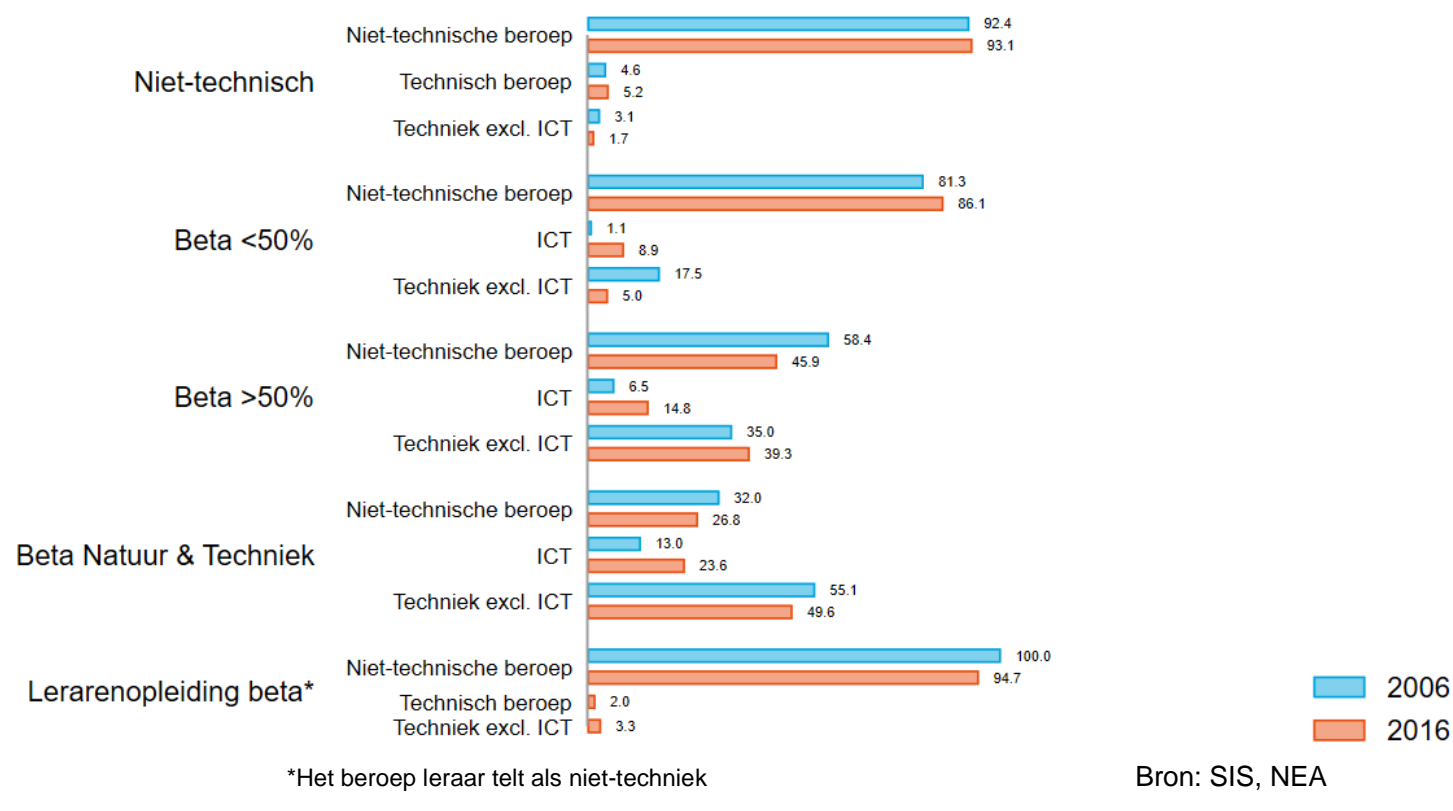

- Statistisch significante afname tussen 2006 en 2016 in het aandeel bèta $(>50 \%)$ en bèta natuur\&techniek geschoolden in niet-technische beroepen op wo-niveau. 


\subsection{Werkzame beroepsbevolking}

Figuur 2.6 percentage technisch gediplomeerden* op mbo2/3-niveau naar beroep

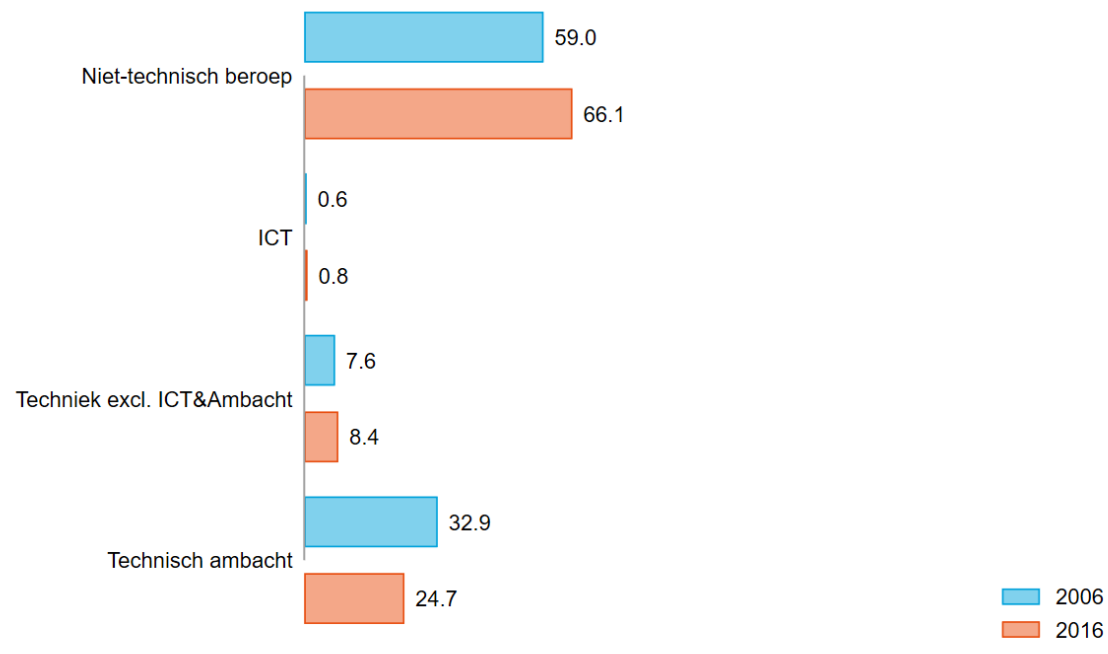

*Technisch gediplomeerden volgens de ROA-definitie: zie Bijlage II

Bron: EBB

- Grootste gedeelte van de technici op mbo-2/3 niveau werkzaam in een niettechnisch beroep.

Figuur 2.7 percentage technisch gediplomeerden* op mbo4-niveau naar beroep

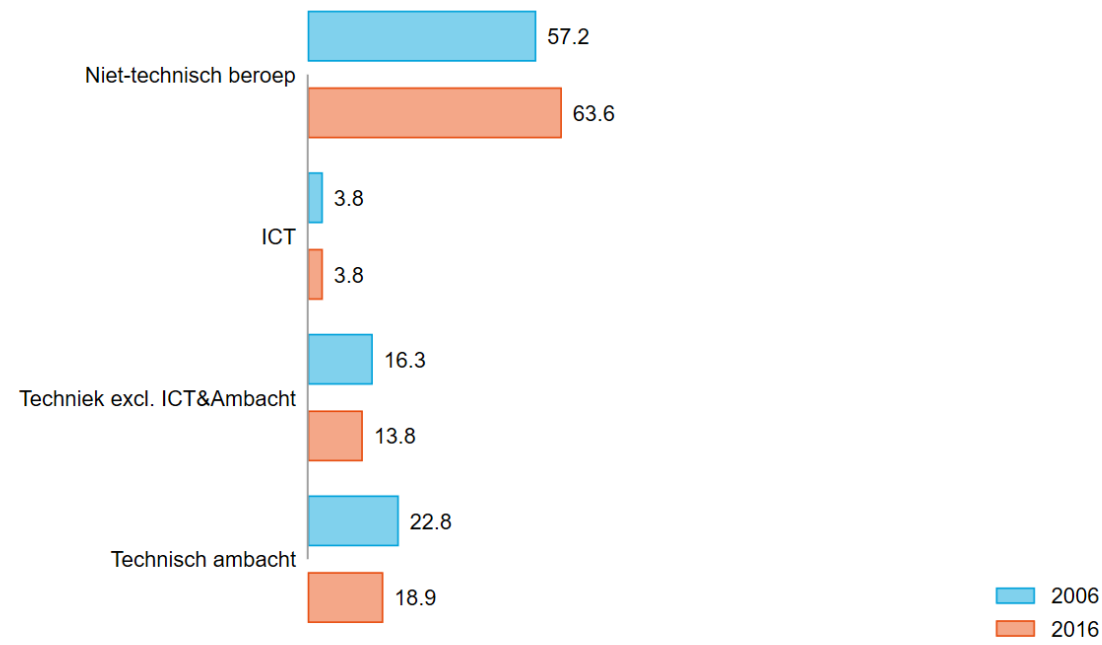

${ }^{*} T e c h n i s c h$ gediplomeerden volgens de ROA-definitie: zie Bijlage II

Bron: EBB

- Grootste gedeelte van de technici op mbo-4 niveau werkzaam in een niettechnisch beroep. 
Figuur 2.8 percentage technisch gediplomeerden* op hbo-niveau naar beroep

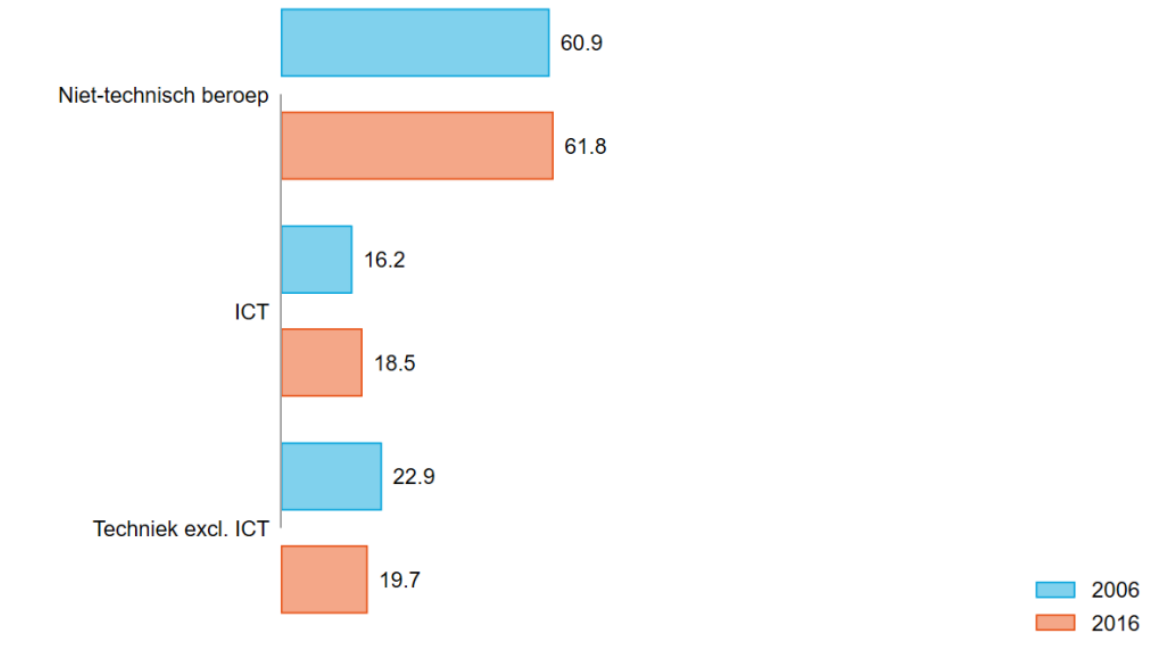

${ }^{*}$ Technisch gediplomeerden volgens de ROA-definitie: zie Bijlage ॥

Bron: EBB

- Rond de $60 \%$ van de technici op hbo-niveau werkzaam in een niettechnisch beroep.

Figuur 2.9 percentage technisch gediplomeerden* op wo-niveau naar beroep

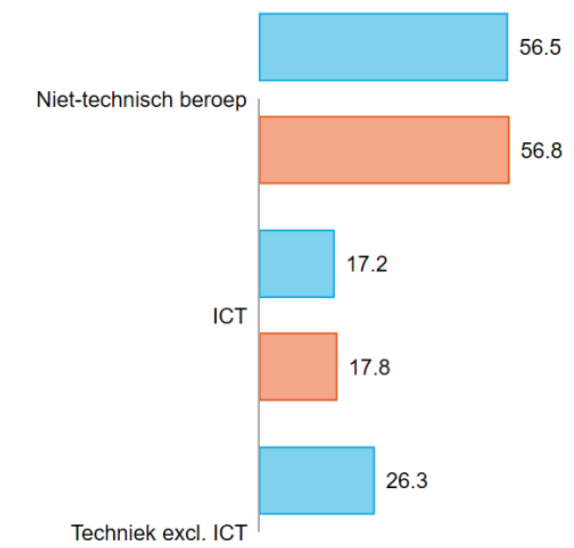

25.3

*Technisch gediplomeerden volgens de ROA-definitie: zie Bijlage II

- Ruim de helft van de technici op wo-niveau werkzaam in een niet-technisch beroep. 


\section{Kenmerken van technici in niet-technische beroepen}

In dit hoofdstuk wordt meer informatie gegeven over de achtergrondkenmerken van de werkenden met een technische opleiding. Daarnaast wordt aangegeven wat de meest voorkomende beroepen zijn onder technici naar opleidingsachtergrond.

\section{Bevindingen:}

- Lage deeltijdfactor in technische beroepen.

- Relatief laag aandeel vrouwen met een technische opleiding in een technisch beroep; het aandeel vrouwen in een technisch beroep is op woniveau het hoogste.

- De meeste hbo- en wo-technici met een bèta natuur\&techniek-opleiding werken in een technisch beroep.

- Ook wo-technici met een bèta>50\%-opleiding werken vaker in een technisch beroep.

- Een meerderheid van de Mbo-ers met een technische opleiding werkt in een technisch of ICT-beroep.

- Verspreiding van technici over niet-technische sector is alleen groter voor mbo4 en hbo in vergelijking met de spreiding van economen over de nieteconomische sector en zorg\&welzijn geschoolden over een andere sector dan de zorg\&welzijn. 


\subsection{Arbeidsmarktkenmerken van technisch gediplomeerden, naar beroep}

Tabel 3.1 kenmerken recent afgestudeerde technici, naar beroep*

\begin{tabular}{|c|c|c|c|c|c|c|c|}
\hline jaar & opleiding & $\begin{array}{l}\text { technisch } \\
\text { beroep }\end{array}$ & $\begin{array}{l}\text { gemiddelde } \\
\text { leeftijd }\end{array}$ & $\begin{array}{l}\text { aandeel } \\
\text { vrouw }\end{array}$ & $\begin{array}{l}\text { aandeel } \\
\text { deeltijd }\end{array}$ & $\begin{array}{l}\text { aandeel migratie- } \\
\text { achtergrond }\end{array}$ & $\begin{array}{l}\text { aantal gewogen } \\
\text { observaties }\end{array}$ \\
\hline 2006 & mbo 2 & 0 & 21,1 & $57,1 \%$ & $57,6 \%$ & $18,7 \%$ & 2480,2 \\
\hline 2016 & mbo 2 & 0 & 21 & $52,6 \%$ & $67,2 \%$ & $27,0 \%$ & 8687,4 \\
\hline 2006 & mbo 2 & 1 & 20,6 & $10,6 \%$ & $33,8 \%$ & $21,2 \%$ & 655,6 \\
\hline 2016 & mbo 2 & 1 & 21,2 & $12,2 \%$ & $42,0 \%$ & $26,2 \%$ & 2813,1 \\
\hline 2006 & mbo 3 & 0 & 23,2 & $91,4 \%$ & $69,8 \%$ & $10,1 \%$ & 6954,6 \\
\hline 2016 & mbo 3 & 0 & 22,1 & $66,8 \%$ & $66,5 \%$ & $21,8 \%$ & 11934,2 \\
\hline 2006 & mbo 3 & 1 & 22,4 & $22,0 \%$ & $27,2 \%$ & $21,5 \%$ & 763,6 \\
\hline 2016 & mbo 3 & 1 & 22,3 & $19,1 \%$ & $29,8 \%$ & $19,9 \%$ & 1909,7 \\
\hline 2006 & mbo 4 & 0 & 23,7 & $78,5 \%$ & $51,5 \%$ & $12,0 \%$ & 10066,3 \\
\hline 2016 & mbo 4 & 0 & 22,4 & $65,6 \%$ & $57,3 \%$ & $19,9 \%$ & 21586,1 \\
\hline 2006 & mbo 4 & 1 & 23,7 & $12,1 \%$ & $13,9 \%$ & $12,3 \%$ & 2600,7 \\
\hline 2016 & mbo 4 & 1 & 22,5 & $12,5 \%$ & $22,1 \%$ & $15,7 \%$ & 4931,1 \\
\hline 2006 & hbo ba & 0 & 24,8 & $65,8 \%$ & $32,6 \%$ & $11,8 \%$ & 23289,1 \\
\hline 2016 & hbo ba & 0 & 25,1 & $64,0 \%$ & $40,5 \%$ & $14,7 \%$ & 28916,6 \\
\hline 2006 & hbo ba & 1 & 25,2 & $14,7 \%$ & $7,9 \%$ & $12,1 \%$ & 5215,4 \\
\hline 2016 & hbo ba & 1 & 25,3 & $18,2 \%$ & $11,7 \%$ & $13,3 \%$ & 5043,2 \\
\hline 2006 & wo ma & 0 & 27,2 & $58,1 \%$ & $24,9 \%$ & $13,7 \%$ & 11165,2 \\
\hline 2016 & wo ma & 0 & 28,4 & $59,5 \%$ & $12,5 \%$ & $19,7 \%$ & 19263,2 \\
\hline 2006 & wo ma & 1 & 26,9 & $33,3 \%$ & $7,8 \%$ & $14,1 \%$ & 4332,3 \\
\hline 2016 & wo ma & 1 & 28 & $42,4 \%$ & $7,2 \%$ & $27,6 \%$ & 9267,1 \\
\hline
\end{tabular}

${ }^{*}$ De aandelen zijn berekend naar opleiding en beroep. Het aandeel mannen is dus gelijk aan $100 \%$ minus het aandeel vrouwen.

- Weinig verschil in leeftijd tussen technische en niet-technische beroepen.

- Weinig verschil in aandeel werkenden met een migratieachtergrond in technische en niet-technische beroepen, behalve op wo-niveau.

- Relatief weinig vrouwen in technisch beroepen.

- Lage deeltijdfactor voor technische beroepen. 
Tabel 3.2 kenmerken technici ${ }^{\star}$ werkend in technische en niet-technische beroepen $^{\star *}$

\begin{tabular}{|c|c|c|c|c|c|c|}
\hline jaar & opleiding & $\begin{array}{l}\text { technisch } \\
\text { beroep }\end{array}$ & $\begin{array}{l}\text { gemiddelde } \\
\text { leeftijd }\end{array}$ & $\begin{array}{l}\text { aandeel } \\
\text { vrouw }\end{array}$ & $\begin{array}{l}\text { aandeel } \\
\text { deeltijd }\end{array}$ & $\begin{array}{l}\text { aandeel migrati- } \\
\text { eachtergrond }\end{array}$ \\
\hline 2006 & $\mathrm{mbo} 2 / 3$ & 0 & 49,8 & $56,3 \%$ & $45,6 \%$ & $19,5 \%$ \\
\hline 2016 & $\mathrm{mbo} 2 / 3$ & 0 & 51,9 & $54,2 \%$ & $46,2 \%$ & $22,5 \%$ \\
\hline 2006 & $\mathrm{mbo} 2 / 3$ & 1 & 40,3 & $6,6 \%$ & $7,6 \%$ & $18,7 \%$ \\
\hline 2016 & $\mathrm{mbo} 2 / 3$ & 1 & 41,7 & $8,1 \%$ & $9,6 \%$ & $21,9 \%$ \\
\hline 2006 & mbo 4 & 0 & 43,7 & $54,8 \%$ & $40,0 \%$ & $12,9 \%$ \\
\hline 2016 & mbo 4 & 0 & 45,5 & $56,5 \%$ & $44,6 \%$ & $15,1 \%$ \\
\hline 2006 & mbo 4 & 1 & 39,3 & $6,9 \%$ & $7,8 \%$ & $12,0 \%$ \\
\hline 2016 & mbo 4 & 1 & 41,9 & $10,2 \%$ & $10,4 \%$ & $15,1 \%$ \\
\hline 2006 & hbo ba & 0 & 45,4 & $52,3 \%$ & $34,5 \%$ & $12,6 \%$ \\
\hline 2016 & hbo ba & 0 & 46,4 & $55,0 \%$ & $36,2 \%$ & $16,3 \%$ \\
\hline 2006 & hbo ba & 1 & 39,0 & $12,2 \%$ & $8,8 \%$ & $12,3 \%$ \\
\hline 2016 & hbo ba & 1 & 41,5 & $13,5 \%$ & $11,4 \%$ & $16,9 \%$ \\
\hline 2006 & wo ma & 0 & 45,1 & $44,3 \%$ & $25,1 \%$ & $23,8 \%$ \\
\hline 2016 & wo ma & 0 & 46,3 & $49,2 \%$ & $23,9 \%$ & $22,9 \%$ \\
\hline 2006 & wo ma & 1 & 39,5 & $20,2 \%$ & $10,2 \%$ & $25,5 \%$ \\
\hline 2016 & wo ma & 1 & 40,5 & $24,2 \%$ & $8,4 \%$ & $24,4 \%$ \\
\hline
\end{tabular}

- Relatief weinig vrouwen in technische beroepen; voornamelijk op lagere opleidingsniveaus.

- $\quad$ Lage deeltijdfactor voor technische beroepen.

\subsection{Gediplomeerden werkzaam buiten hun beroependomein}

Tabel 3.3 Werkenden met een economie, zorg\&welzijn, of techniek opleiding die werkzaam zijn buiten de, respectievelijk, economie sector, zorg\&welzijn sector, en techniek sector.

\begin{tabular}{|c|c|c|c|c|c|}
\hline & MBO2 & MBO3 & MBO4 & $\mathrm{HBO}$ & WO \\
\hline \multicolumn{6}{|c|}{ Economie } \\
\hline 2006 & 73,5 & 39,9 & 36,6 & 30,4 & 31,2 \\
\hline 2016 & 72,0 & 55,2 & 44,5 & 24,1 & 26,5 \\
\hline \multicolumn{6}{|c|}{ Zorg \& Welzijn } \\
\hline 2006 & 71,2 & 72,6 & 38,1 & 25,1 & 57,9 \\
\hline 2016 & 63,5 & 48,1 & 41,1 & 24,5 & 61,7 \\
\hline \multicolumn{6}{|c|}{ Techniek } \\
\hline 2006 & 7,7 & 30,0 & 41,1 & 61,9 & 45,5 \\
\hline 2016 & 36,8 & 56,7 & 64,3 & 66,1 & 35,0 \\
\hline
\end{tabular}

- $\quad$ Op wo-niveau werkt het grootste deel van de werkenden met een economische opleiding binnen de economische sector. Hetzelfde geldt voor 
technici. Werkenden met een opleiding in zorg\&welzijn werken voornamelijk buiten deze sector.

- Op hbo-niveau werkt het grootste deel van de werkenden met een hboopleiding economie of zorg\&welzijn in de economische (zorg\&welzijn) sector. Tweedere van de technici werkt buiten de techniek sector.

- Op het mbo3/4-niveau werkt het grootste deel van de technici buiten de eigen sector in 2016. Voor zorg\&welzijn en economie is dit niet het geval (m.u.v. mbo3 economie). Voor mbo2 is het beeld omgekeerd.

\subsection{Meest voorkomende beroepen van technisch gediplomeerden}

In tabel 3.4 worden de meest voorkomende beroepsklassen waarin technisch geschoolden werkzaam zijn weergegeven. Deze indeling is gebaseerd op de ROAindeling en te vinden in Bijlage 1. Over het algemeen is er minder informatie beschikbaar over beroepen op een meer gedetailleerd niveau omdat de aantallen dan veel lager en vaker ook minder betrouwbaar zijn. De indeling van beroepen staat los van de sectoren waarin deze beroepen voorkomen. Manager is een niettechnisch beroep, ook als het een manager is bij een technisch bedrijf in de technische sector.

Tabel 3.4 top 3 meest voorkomende beroepen van technisch geschoolden, naar beroepsklasse

\begin{tabular}{|r|l|l|l|r|}
\hline jaar & opleiding & beroepsklasse (indeling ROA)* & opleiding & $\begin{array}{r}\text { Aandeel } \\
(\%)\end{array}$ \\
\hline 2006 & mbo 2 & Technische beroepen & Technisch & 64,6 \\
\hline 2006 & mbo 2 & Transport en logistiek beroepen & Technisch & 11,9 \\
\hline 2006 & mbo 2 & ICT beroepen & Technisch & 7,8 \\
\hline 2016 & mbo 2 & Technische beroepen & Technisch & 60,5 \\
\hline 2016 & mbo 2 & Transport en logistiek beroepen & Technisch & 11,1 \\
\hline 2016 & mbo 2 & Agrarische beroepen & & 6,2 \\
\hline & & & Technisch & 33,1 \\
\hline 2006 & mbo 3 & ICT beroepen & Technisch & 33,0 \\
\hline 2006 & mbo 3 & Technische beroepen & Technisch & 9,8 \\
\hline 2006 & mbo 3 & Commerciële beroepen & Technisch & 37,1 \\
\hline 2016 & mbo 3 & Technische beroepen & Technisch & 15,5 \\
\hline 2016 & mbo 3 & Transport en logistiek beroepen & Technisch & 13,0 \\
\hline 2016 & mbo 3 & ICT beroepen & & \\
\hline & & & Technisch & 55,6 \\
\hline 2006 & mbo 4 & Technische beroepen & Technisch & 12,0 \\
\hline 2006 & mbo 4 & ICT beroepen & Technisch & 7,8 \\
\hline 2006 & mbo 4 & Creatieve en taalkundige beroepen & Technisch & 37,6 \\
\hline 2016 & mbo 4 & Technische beroepen & Technisch & 19,5 \\
\hline 2016 & mbo 4 & ICT beroepen & Technisch & 9,7 \\
\hline 2016 & mbo 4 & Creatieve en taalkundige beroepen & & \\
\hline & & & Beta $<50 \%$ & 67,9 \\
\hline 2006 & hbo ba & Zorg en welzijn beroepen & Beta $<50 \%$ & 9,8 \\
\hline 2006 & hbo ba & Bedrijfseconomische en administratieve & & \\
\hline & & & & \\
\hline
\end{tabular}




\begin{tabular}{|c|c|c|c|c|}
\hline & & beroepen & & \\
\hline 2006 & hbo ba & Commerciële beroepen & Beta $<50 \%$ & 4,4 \\
\hline 2016 & hbo ba & Zorg en welzijn beroepen & Beta $<50 \%$ & 76,3 \\
\hline 2016 & hbo ba & $\begin{array}{l}\text { Bedrijfseconomische en administratieve } \\
\text { beroepen }\end{array}$ & Beta $<50 \%$ & 4,3 \\
\hline 2016 & hbo ba & Commerciële beroepen & Beta $<50 \%$ & 4,0 \\
\hline 2006 & hbo ba & Zorg en welzijn beroepen & Beta $>50 \%$ & 28,2 \\
\hline 2006 & hbo ba & Technische beroepen & Beta $>50 \%$ & 23,9 \\
\hline 2006 & hbo ba & $\begin{array}{l}\text { Bedrijfseconomische en administratieve } \\
\text { beroepen }\end{array}$ & Beta $>50 \%$ & 20,0 \\
\hline 2016 & hbo ba & Zorg en welzijn beroepen & Beta $>50 \%$ & 40,5 \\
\hline 2016 & hbo ba & Technische beroepen & Beta $>50 \%$ & 29,9 \\
\hline 2016 & hbo ba & $\begin{array}{l}\text { Bedrijfseconomische en administratieve } \\
\text { beroepen }\end{array}$ & Beta $>50 \%$ & 8,3 \\
\hline 2006 & hbo ba & Technische beroepen & $\begin{array}{l}\text { Beta Natuur } \\
\text { \& Techniek }\end{array}$ & 35,3 \\
\hline 2006 & hbo ba & ICT beroepen & $\begin{array}{l}\text { Beta Natuur } \\
\text { \& Techniek }\end{array}$ & 32,2 \\
\hline 2006 & hbo ba & $\begin{array}{l}\text { Bedrijfseconomische en administratieve } \\
\text { beroepen }\end{array}$ & $\begin{array}{l}\text { Beta Natuur } \\
\text { \& Techniek }\end{array}$ & 11,9 \\
\hline 2016 & hbo ba & Technische beroepen & $\begin{array}{l}\text { Beta Natuur } \\
\text { \& Techniek }\end{array}$ & 34,1 \\
\hline 2016 & hbo ba & ICT beroepen & $\begin{array}{l}\text { Beta Natuur } \\
\text { \& Techniek }\end{array}$ & 24,5 \\
\hline 2016 & hbo ba & $\begin{array}{l}\text { Bedrijfseconomische en administratieve } \\
\text { beroepen }\end{array}$ & $\begin{array}{l}\text { Beta Natuur } \\
\text { \& Techniek }\end{array}$ & 13,8 \\
\hline 2006 & wo ma & Zorg en welzijn beroepen & Beta $<50 \%$ & 64,1 \\
\hline 2006 & wo ma & Technische beroepen & Beta $<50 \%$ & 17,5 \\
\hline 2006 & wo ma & $\begin{array}{l}\text { Bedrijfseconomische en administratieve } \\
\text { beroepen }\end{array}$ & Beta $<50 \%$ & 10,9 \\
\hline 2016 & wo ma & Zorg en welzijn beroepen & Beta $<50 \%$ & 56,8 \\
\hline 2016 & wo ma & $\begin{array}{l}\text { Bedrijfseconomische en administratieve } \\
\text { beroepen }\end{array}$ & Beta $<50 \%$ & 14,8 \\
\hline 2016 & wo ma & ICT beroepen & Beta $<50 \%$ & 8,9 \\
\hline 2006 & wo ma & Technische beroepen & Beta $>50 \%$ & 35,0 \\
\hline 2006 & wo ma & $\begin{array}{l}\text { Bedrijfseconomische en administratieve } \\
\text { beroepen }\end{array}$ & Beta $>50 \%$ & 22,9 \\
\hline 2006 & wo ma & Zorg en welzijn beroepen & Beta $>50 \%$ & 10,8 \\
\hline 2016 & wo ma & Technische beroepen & Beta $>50 \%$ & 39,3 \\
\hline 2016 & wo ma & $\begin{array}{l}\text { Bedrijfseconomische en administratieve } \\
\text { beroepen }\end{array}$ & Beta $>50 \%$ & 22,3 \\
\hline
\end{tabular}




\begin{tabular}{|l|l|l|l|r|}
\hline 2016 & wo ma & ICT beroepen & Beta $>50 \%$ & 14,8 \\
\hline 2006 & wo ma & Technische beroepen & $\begin{array}{l}\text { Beta Natuur } \\
\text { \& Techniek }\end{array}$ & 55,1 \\
\hline 2006 & wo ma & $\begin{array}{l}\text { Bedrijfseconomische en administratieve } \\
\text { beroepen }\end{array}$ & $\begin{array}{l}\text { Beta Natuur } \\
\text { \& Techniek }\end{array}$ & 18,3 \\
\hline 2006 & wo ma & ICT beroepen & $\begin{array}{l}\text { Beta Natuur } \\
\text { \& Techniek }\end{array}$ & 13,0 \\
\hline 2016 & wo ma & Technische beroepen & $\begin{array}{l}\text { Beta Natuur } \\
\text { \& Techniek }\end{array}$ & 49,6 \\
\hline 2016 & wo ma & ICT beroepen & $\begin{array}{l}\text { Beta Natuur } \\
\text { \& Techniek }\end{array}$ & 23,6 \\
\hline 2016 & wo ma & $\begin{array}{l}\text { Bedrijfseconomische en administratieve } \\
\text { beroepen }\end{array}$ & $\begin{array}{l}\text { Beta Natuur } \\
\text { \& Techniek }\end{array}$ & 10,2 \\
\hline *zie bijlage 1 & & Bron:SIS, NEA \\
\hline
\end{tabular}

- Weinig verandering in aandeel van beroepen voor mbo2-technici tussen 2006 en 2016.

- $\quad$ Er is een afname tussen 2006 en 2016 van het aandeel ICT-beroepen voor mbo3-technici.

- $\quad$ Er is een afname van het aandeel technische beroepen voor mbo4-technici tussen 2006 en 2016.

- $\quad$ Er is een afname van het aandeel ICT-beroepen voor hbo-technici tussen 2006 en 2016.

- Het grootse deel van de hbo-ers met een bèta $>50 \%$-opleiding heeft een zorg\&welzijn beroep.

- Tussen 2006 en 2016 was er een toename van het aandeel ICT-beroepen voor wo-technici.

- Tussen 2006 en 2016 was er een afname van het aandeel bedrijfseconomische en administratieve beroepen voor wo-technici met een bèta natuur\&techniek-opleiding. 


\section{$4 \quad$ Subjectieve aansluiting onderwijs-arbeidsmarkt}

De aansluiting van werkenden met een technische opleiding op de arbeidsmarkt is mogelijk een belangrijke factor voor het verklaren van de uitstroom van technici naar niet-technische beroepen. Daarnaast speelt de vraag naar technisch gediplomeerden vanuit niet-technische beroepen een rol. In dit hoofdstuk wordt aangegeven of recent gediplomeerde technici vinden dat hun opleiding goed aansluit bij hun huidige functie of arbeidsmarktpositie. Dit is inzichtelijk voor de vraag of techniekopleidingen voldoende goed voorbereiden op de behoeften van de arbeidsmarkt. Hierbij wordt onderscheid gemaakt naar beroep en opleiding. In tabellen 4.1 en 4.2 staat de omschrijving van de data. De regressieanalyse in tabel 4.3 geeft de relatie weer tussen het oordeel van schoolverlaters over de mate waarin men vindt dat de opleiding wel of niet goed aansluit bij hun functie of arbeidsmarktpositie.

\section{Bevindingen:}

- $\quad$ Over de gehele linie geven mbo-technici minder vaak aan dat de aansluiting onderwijs-arbeidsmarkt goed is dan hoger opgeleide technici.

- Voor technici met een mbo-opleiding is de subjectieve aansluiting op de arbeidsmarkt beter voor een technisch of ICT-beroep dan voor een niettechnisch beroep.

- Voor technici met een hbo- of wo-opleiding is de subjectieve aansluiting tussen onderwijs-arbeidsmarkt niet per se beter als zij in een technisch beroep werken.

\subsection{Verdeling subjectieve aansluiting over opleidingen en beroepen}

Tabel 4.1 percentage technici met goed en slechte aansluiting arbeidsmarkt, naar opleiding

\begin{tabular}{|l|l|l|l|l|l|l|l|l|}
\hline $\begin{array}{l}\text { opleiding } \\
\begin{array}{l}\text { Aansluiting } \\
\text { arbeidsmarkt }\end{array}\end{array}$ & goed & slecht & goed & slecht & goed & slecht & goed & slecht \\
\hline MBO 2 & 72,0 & 28,0 & & & & & & \\
\hline MBO 3 & 66,5 & 33,5 & & & & & & \\
\hline MBO 4 & 68,0 & 32,0 & & & & & & \\
\hline HBO & & & 78,7 & 21,3 & 80,9 & 19,1 & 78,5 & 21,5 \\
\hline WO & & & 90,2 & 9,8 & 86,5 & 13,5 & 89,1 & 10,9 \\
\hline
\end{tabular}

- $\quad$ Technici met een hbo- en wo-opleiding geven vaker aan dat de aansluiting onderwijs-arbeidsmarkt goed is dan technici met een mbo-opleiding. 
Tabel 4.2 percentage technici met goed en slechte aansluiting arbeidsmarkt, naar beroep

\begin{tabular}{|c|c|c|c|c|c|c|c|c|c|c|}
\hline beroep & \multicolumn{2}{|c|}{$\begin{array}{c}\text { Niet- } \\
\text { technisch }\end{array}$} & \multicolumn{2}{|c|}{$\mathrm{ICT}$} & \multicolumn{2}{|c|}{$\begin{array}{c}\text { Techniek } \\
\text { excl. ICT \& } \\
\text { ambacht }\end{array}$} & \multicolumn{2}{|c|}{$\begin{array}{l}\text { Technisch } \\
\text { Ambacht }\end{array}$} & \multicolumn{2}{|c|}{$\begin{array}{l}\text { Techniek } \\
\text { excl. ICT }\end{array}$} \\
\hline $\begin{array}{l}\text { Aansluiting } \\
\text { arbeidsmarkt }\end{array}$ & goed & slecht & goed & Slecht & goed & slecht & goed & slecht & goed & slecht \\
\hline MBO 2 & 60,9 & 39,08 & 66,5 & 33,5 & 69,0 & 31,0 & 81,1 & 18,9 & & \\
\hline MBO 3 & 60,2 & 39,8 & 75,3 & 24,7 & 66,5 & 33,5 & 72,1 & 27,9 & & \\
\hline MBO 4 & 61,6 & 38,4 & 70,4 & 29,6 & 70,1 & 29,9 & 74,3 & 25,7 & & \\
\hline $\mathrm{HBO}$ & 78,7 & 21,3 & 78,5 & 21,5 & & & & & 79,6 & 20,4 \\
\hline WO & 88,6 & 11,4 & 86,1 & 13,9 & & & & & 90,3 & 9,4 \\
\hline
\end{tabular}

- $\quad$ Technici met een hbo- en wo-opleiding geven vaker aan dat de aansluiting onderwijs-arbeidsmarkt goed is dan technici met een mbo-opleiding.

- Voor niet-technische beroepen is de subjectieve aansluiting van de technische opleiding met de arbeidsmarkt voor hbo- en wo-technici over het algemeen goed.

- Mbo-technici geven aan dat de aansluiting onderwijs-arbeidsmarkt iets minder goed is voor niet-technische beroepen.

\subsection{Samenhang tussen subjectieve aansluiting en opleiding}

Tabel 4.3 geeft de resultaten weer van een regressieanalyse waarin recent gediplomeerde technici aangeven of hun huidige functie goed aansluit bij hun studie. In deze regressie is gecorrigeerd voor demografische kenmerken (geslacht, en migratie-achtergrond) en ervaring (leeftijd). Daarnaast is gecorrigeerd voor het jaar waarin de enquête is afgenomen en of de respondent parttime werkt. De regressiecoëfficiënten moeten geïnterpreteerd worden ten opzichte van het werken in een niet-techniek beroep.

Tabel 4.3 OLS regressie voor de subjectieve aansluiting tussen opleiding en functie, gediplomeerde technici

\begin{tabular}{|c|c|c|c|c|c|}
\hline $\begin{array}{l}\text { Aansluiting } \\
\text { functie/arbeidsmarkt }\end{array}$ & MBO 2 & MBO 3 & MBO 4 & $\mathrm{HBO}$ & WO $^{1}$ \\
\hline \multirow{2}{*}{$\mathrm{ICT}$} & $0,098^{\star *}$ & $0,139^{\star \star \star}$ & $0,080^{\star \star *}$ & 0,009 & $-0,049^{* \star *}$ \\
\hline & $(0,038)$ & $(0,023)$ & $(0,014)$ & $(0,008)$ & $(0,007)$ \\
\hline \multirow[t]{2}{*}{ Techniek excl. ICT \& ambacht } & $0,088^{* * *}$ & $0,060^{\star *}$ & $0,076^{\star * \star}$ & & \\
\hline & $(0,026)$ & $(0,028)$ & $(0,013)$ & & \\
\hline \multirow[t]{2}{*}{ Technisch ambacht } & $0,197^{\star * *}$ & $0,101^{* * *}$ & $0,104^{* * *}$ & & \\
\hline & $(0,016)$ & $(0,019)$ & $(0,012)$ & & \\
\hline \multirow[t]{2}{*}{ Techniek excl. ICT } & & & & $0,014^{*}$ & 0,007 \\
\hline & & & & $(0,007)$ & $(0,005)$ \\
\hline Observaties & 3.578 & 3.378 & 10.414 & 23.745 & 19.178 \\
\hline R-kwadraat & 0,067 & 0,060 & 0,030 & 0,004 & 0,021 \\
\hline
\end{tabular}

Standaardfouten staan tussen haakjes. ${ }^{* * *} p<0.01,{ }^{* *} p<0.05,{ }^{*} p<0.1$

Leeftijd, leeftijd ${ }^{2}$, geslacht, herkomst, jaar, en dummy parttime werk als controlevariabelen. Geen techniek

beroep is de referentiecategorie.

${ }^{1}$ Vanaf 2016 is voor WO de vraagstelling aangepast. 
- De subjectieve aansluiting voor mbo-technici op de arbeidsmarkt is beter voor (alle) technische beroepen dan voor niet-technische beroepen.

- De subjectieve aansluiting voor hbo-technici op de arbeidsmarkt is beter voor technische beroepen excl. ICT dan voor niet-technische beroepen. Er is geen verschil tussen de aansluiting voor ICT-beroepen en niet-technische beroepen voor hbo-technici.

- De subjectieve aansluiting voor wo-technici op de arbeidsmarkt is slechter voor ICT-beroepen dan voor niet-technische beroepen. $\mathrm{Er}$ is geen verschil tussen de subjectieve aansluiting voor technische beroepen (excl. ICT) en niet-technische beroepen voor wo-technici. 


\section{Lonen}

Naast de aansluiting van het technisch onderwijs op de arbeidsmarkt, kan het loon in verschillende beroepen een verklaring zijn voor de uitstroom van technisch personeel naar niet-technische beroepen. Een hoger loon kan een indicatie zijn voor een grotere vraag naar technisch geschoolden in een beroep, of een beperkter aanbod van technische geschoolden in dat beroep. Een lager loon kan het gevolg zijn van een groter aanbod van technisch personeel in dat beroep dan de vraag naar technisch personeel. Hierbij kan internationalisering en outsourcing in technische beroepen een rol spelen.

\section{Bevindingen:}

- $\quad$ Lonen in niet-technische beroepen zijn hoger voor wo-technici dan de lonen in technische beroepen.

- Gemiddeld genomen zijn de lonen voor technische beroepen hoger dan voor niet-technische beroepen voor mbo-technici.

- Uit de data kan geen conclusie getrokken worden of, en in welke mate, lonen doorslaggevend zijn voor de beroepskeuze van technici.

\subsection{Uurloon van recent gediplomeerde technici}

Tabel 5.1 geeft de resultaten weer van een regressieanalyse waarin het uurloon van recent gediplomeerde technici wordt vergeleken over verschillende beroepen. In deze regressie is gecorrigeerd voor demografische kenmerken (geslacht, en migratie-achtergrond) en ervaring (leeftijd). Daarnaast is gecorrigeerd voor het jaar waarin de enquête is afgenomen en of de respondent parttime werkt. De regressiecoëfficiënten moeten geïnterpreteerd worden ten opzichte van het werken in een niet-techniek beroep.

Tabel 5.1 OLS-regressie voor het uurloon, recent gediplomeerde technici

\begin{tabular}{|c|c|c|c|c|c|}
\hline log uurloon technici & MBO2 & MBO3 & MBO4 & $\mathrm{HBO}$ & WO \\
\hline \multirow[t]{2}{*}{ ICT } & $-0,108^{* * *}$ & $0,117^{\star \star \star}$ & $0,023^{* *}$ & $0,012^{\star \star}$ & $-0,031^{* \star *}$ \\
\hline & $(0,036)$ & $(0,016)$ & $(0,009)$ & $(0,005)$ & $(0,006)$ \\
\hline \multirow{2}{*}{$\begin{array}{l}\text { Techniek excl. } \\
\text { ICT\&ambacht }\end{array}$} & $0,063^{\star * *}$ & $0,237^{* * *}$ & $0,115^{\star \star *}$ & & \\
\hline & $(0,023)$ & $(0,021)$ & $(0,008)$ & & \\
\hline \multirow[t]{2}{*}{ Technisch ambacht } & $0,033^{* *}$ & $-0,032^{* *}$ & $0,018^{* *}$ & & \\
\hline & $(0,015)$ & $(0,014)$ & $(0,008)$ & & \\
\hline \multirow[t]{2}{*}{ Techniek excl. ICT } & & & & $-0,008^{*}$ & $-0,093^{* * *}$ \\
\hline & & & & $(0,004)$ & $(0,004)$ \\
\hline Observaties & 1.970 & 2.293 & 7.950 & 20.902 & 17.538 \\
\hline R-kwadraat & 0,186 & 0,222 & 0,161 & 0,051 & 0,085 \\
\hline
\end{tabular}

Standaardfouten staan tussen haakjes. ${ }^{* * *} p<0.01,{ }^{* *} p<0.05,{ }^{*} p<0.1$

Leeftijd, leeftijd ${ }^{2}$, geslacht, herkomst, jaar, en dummy parttime werk als controlevariabelen. Geen techniek beroep is de referentiecategorie. 
- Op wo-niveau is het loon van technici die een technisch beroep hebben lager dan voor technici die een niet-technisch beroep hebben.

- Voor hbo-technici is het loon hoger in ICT-beroepen dan in niet-technische beroepen, maar lager voor technische beroepen excl. ICT.

- Op mbo4-niveau is het loon voor technici hoger in technische beroepen dan in niet-technische beroepen.

- Op mbo3-niveau is het loon voor technici hoger in technische beroepen dan in niet-technische beroepen en technische ambachten.

- Op mbo2-niveau is het loon voor technici hoger in technische beroepen dan in niet-technische beroepen en ICT-beroepen.

- Resultaten kunnen het gevolg zijn van selectie van technici op vaardigheden: de beste technici kunnen onderhandelen over hun loon en de baan met het hoogste loon kiezen.

Tabel 5.2 Gemiddeld uurloon naar opleiding en beroep, recent gediplomeerden 2006 en 2016

\begin{tabular}{|c|c|c|c|c|}
\hline jaar & opleiding & beroep & opleiding & $\begin{array}{l}\text { gemiddeld bruto } \\
\text { uurloon }(€)^{*}\end{array}$ \\
\hline 2006 & hbo ba & Niet-technisch beroep & Niet-technisch & 14,3 \\
\hline 2016 & hbo ba & Niet-technisch beroep & Niet-technisch & 13,7 \\
\hline 2006 & hbo ba & ICT & Niet-technisch & 14,5 \\
\hline 2016 & hbo ba & ICT & Niet-technisch & 13,6 \\
\hline 2006 & hbo ba & Techniek excl. ICT & Niet-technisch & 15,6 \\
\hline 2016 & hbo ba & Techniek excl. ICT & Niet-technisch & 14,6 \\
\hline 2006 & hbo ba & Niet-technisch beroep & Beta $<50 \%$ & 15,8 \\
\hline 2016 & hbo ba & Niet-technisch beroep & Beta $<50 \%$ & 14,9 \\
\hline 2006 & hbo ba & ICT & Beta $<50 \%$ & 14,6 \\
\hline 2016 & hbo ba & ICT & Beta $<50 \%$ & 14,3 \\
\hline 2006 & hbo ba & Techniek excl. ICT & Beta $<50 \%$ & 14,5 \\
\hline 2016 & hbo ba & Techniek excl. ICT & Beta $<50 \%$ & 13,0 \\
\hline 2006 & hbo ba & Niet-technisch beroep & Beta $>50 \%$ & 14,5 \\
\hline 2016 & hbo ba & Niet-technisch beroep & Beta $>50 \%$ & 14,2 \\
\hline 2006 & hbo ba & ICT & Beta $>50 \%$ & 13,9 \\
\hline 2016 & hbo ba & ICT & Beta $>50 \%$ & 16,2 \\
\hline 2006 & hbo ba & Techniek excl. ICT & Beta $>50 \%$ & 14,6 \\
\hline 2016 & hbo ba & Techniek excl. ICT & Beta $>50 \%$ & 13,6 \\
\hline 2006 & hbo ba & Niet-technisch beroep & $\begin{array}{l}\text { Beta Natuur \& } \\
\text { Techniek }\end{array}$ & 14,9 \\
\hline 2016 & hbo ba & Niet-technisch beroep & $\begin{array}{l}\text { Beta Natuur \& } \\
\text { Techniek }\end{array}$ & 13,8 \\
\hline 2006 & hbo ba & ICT & $\begin{array}{l}\text { Beta Natuur \& } \\
\text { Techniek }\end{array}$ & 15,0 \\
\hline 2016 & hbo ba & ICT & Beta Natuur \& & 14,6 \\
\hline
\end{tabular}




\begin{tabular}{|c|c|c|c|c|}
\hline & & & Techniek & \\
\hline 2006 & hbo ba & Techniek excl. ICT & $\begin{array}{l}\text { Beta Natuur \& } \\
\text { Techniek }\end{array}$ & 14,7 \\
\hline 2016 & hbo ba & Techniek excl. ICT & $\begin{array}{l}\text { Beta Natuur \& } \\
\text { Techniek }\end{array}$ & 14,6 \\
\hline 2006 & wo ma & Niet-technisch beroep & Niet-technisch & 17,5 \\
\hline 2016 & wo ma & Niet-technisch beroep & Niet-technisch & 16,5 \\
\hline 2006 & wo ma & ICT & Niet-technisch & 17,0 \\
\hline 2016 & wo ma & ICT & Niet-technisch & 15,9 \\
\hline 2006 & wo ma & Techniek excl. ICT & Niet-technisch & 16,9 \\
\hline 2016 & wo ma & Techniek excl. ICT & Niet-technisch & 15,5 \\
\hline 2006 & wo ma & Niet-technisch beroep & Beta $<50 \%$ & 19,1 \\
\hline 2016 & wo ma & Niet-technisch beroep & Beta $<50 \%$ & 19,2 \\
\hline 2006 & wo ma & ICT & Beta $<50 \%$ & 18,2 \\
\hline 2016 & wo ma & ICT & Beta $<50 \%$ & 17,6 \\
\hline 2006 & wo ma & Techniek excl. ICT & Beta $<50 \%$ & 17,3 \\
\hline 2016 & wo ma & Techniek excl. ICT & Beta $<50 \%$ & 16,9 \\
\hline 2006 & wo ma & Niet-technisch beroep & Beta $>50 \%$ & 16,9 \\
\hline 2016 & wo ma & Niet-technisch beroep & Beta $>50 \%$ & 16,8 \\
\hline 2006 & wo ma & ICT & Beta $>50 \%$ & 16,3 \\
\hline 2016 & wo ma & ICT & Beta $>50 \%$ & 17,3 \\
\hline 2006 & wo ma & Techniek excl. ICT & Beta $>50 \%$ & 15,9 \\
\hline 2016 & wo ma & Techniek excl. ICT & Beta $>50 \%$ & 16,0 \\
\hline 2006 & wo ma & Niet-technisch beroep & $\begin{array}{l}\text { Beta Natuur \& } \\
\text { Techniek }\end{array}$ & 18,2 \\
\hline 2016 & wo ma & Niet-technisch beroep & $\begin{array}{l}\text { Beta Natuur \& } \\
\text { Techniek }\end{array}$ & 16,8 \\
\hline 2006 & wo ma & ICT & $\begin{array}{l}\text { Beta Natuur \& } \\
\text { Techniek }\end{array}$ & 17,6 \\
\hline 2016 & wo ma & ICT & $\begin{array}{l}\text { Beta Natuur \& } \\
\text { Techniek }\end{array}$ & 17,8 \\
\hline 2006 & wo ma & Techniek excl. ICT & $\begin{array}{l}\text { Beta Natuur \& } \\
\text { Techniek }\end{array}$ & 16,6 \\
\hline 2016 & wo ma & Techniek excl. ICT & $\begin{array}{l}\text { Beta Natuur \& } \\
\text { Techniek }\end{array}$ & 16,8 \\
\hline
\end{tabular}

Bron: SIS, NEA

${ }^{*}$ Het bruto uurloon is gemeten 1,5 jaar na afstuderen en voor inflatie gecorrigeerd.

- Het gemiddelde uurloon ligt voor (bijna) alle werkenden in 2016 lager dan in 2006. Dit is vergelijkbaar met de gemiddelde loonontwikkeling in Nederland en is nog het gevolg van de Grote Recessie die in 2008 begon (ROA 2017a).

- Uit ander onderzoek blijkt dat de gemiddelde lonen van hoger opgeleiden sneller herstellen na de recessie dan lonen van mbo-ers (ROA 2017a). 
Tabel 5.3 geeft de resultaten weer van een regressieanalyse waarin het uurloon van recent gediplomeerde technici op hbo- en wo-niveau wordt vergeleken over verschillende beroepen en opleidingen. In deze regressie is gecorrigeerd voor demografische kenmerken (geslacht, en migratie-achtergrond) en ervaring (leeftijd). Daarnaast is gecorrigeerd voor het jaar waarin de enquete is afgenomen en of de respondent partime werkt. De regressiecoëfficiënten moeten geïnterpreteerd worden ten opzichte van het werken in een niet-techniek beroep.

Tabel 5.3 OLS-regressie voor het uurloon, recent gediplomeerde technici naar techniekopleiding

\begin{tabular}{|c|c|c|c|c|c|c|}
\hline $\begin{array}{l}\text { log uurloon } \\
\text { technici }\end{array}$ & $\begin{array}{l}\text { HBO } \\
\text { Beta } \\
<50 \%\end{array}$ & $\begin{array}{l}\text { HBO } \\
\text { Beta } \\
>50 \%\end{array}$ & $\begin{array}{l}\text { HBO } \\
\text { Beta Natuur } \\
\text { \&Techniek }\end{array}$ & $\begin{array}{l}\text { WO } \\
\text { Beta } \\
<50 \%\end{array}$ & $\begin{array}{l}\text { WO } \\
\text { Beta } \\
>50 \%\end{array}$ & $\begin{array}{l}\text { WO } \\
\text { Beta Natuur } \\
\text { \&Techniek }\end{array}$ \\
\hline ICT & $-0,035^{\star *}$ & $0,095^{\star *}$ & $0,035^{\star \star \star}$ & $-0,059^{* \star *}$ & $0,048^{* *}$ & $0,015^{*}$ \\
\hline & $(0,016)$ & $(0,041)$ & $(0,005)$ & $(0,013)$ & $(0,019)$ & $(0,008)$ \\
\hline Techniek & $-0,083^{* \star *}$ & $-0,015$ & $0,024^{* \star *}$ & $-0,099^{* * *}$ & $-0,042^{* \star *}$ & $-0,043^{\star \star *}$ \\
\hline & $(0,016)$ & $(0,015)$ & $(0,004)$ & $(0,010)$ & $(0,013)$ & $(0,006)$ \\
\hline Observaties & 8.096 & 1.222 & 11.124 & 6.441 & 2.168 & 8.722 \\
\hline R-kwadraat & 0,048 & 0,049 & 0,096 & 0,106 & 0,050 & 0,056 \\
\hline
\end{tabular}

Standaardfouten staan tussen haakjes. ${ }^{* * *} p<0.01,{ }^{* *} p<0.05,{ }^{*} p<0.1$

Leeftijd, leeftijd ${ }^{2}$, geslacht, herkomst, jaar, en dummy parttime werk als controlevariabelen. Geen techniek beroep is de referentiecategorie.

- Voor wo-technici zijn de lonen hoger in niet-technische beroepen dan in technische beroepen, met uitzondering van de ICT-beroepen voor bèta natuur\&techniek-gediplomeerden en bèta> $50 \%$-gediplomeerden.

- Voor hbo-technici zijn de lonen hoger in technische beroepen dan in niettechnische beroepen voor bèta natuur\&techniek-gediplomeerden. Voor bèta $<50 \%$-gediplomeerden zijn de lonen lager in technische beroepen dan in niet-technische beroepen. 


\subsection{Uurloon van technici op de arbeidsmarkt}

Tabel 5.4 geeft de resultaten weer van een regressieanalyse waarin het uurloon van technici op de arbeidsmarkt (over alle leeftijden) wordt vergeleken over verschillende beroepen. In deze regressie is gecorrigeerd voor demografische kenmerken (geslacht, en migratie-achtergrond) en ervaring (leeftijd). Daarnaast is gecorrigeerd voor het jaar waarin de enquête is afgenomen en of de respondent parttime werkt. De regressiecoëfficiënten moeten geïnterpreteerd worden ten opzichte van het werken in een niet-techniek beroep.

Tabel 5.4 OLS-regressie voor het uurloon, technici op de arbeidsmarkt

\begin{tabular}{|c|c|c|c|c|}
\hline log uurloon technici ${ }^{\$}$ & $\mathrm{MBO} 2 / 3$ & $\mathrm{MBO} 4$ & $\mathrm{HBO}$ & WO \\
\hline ICT & $0,142^{* * *}$ & $0,082^{* *}$ & $-0,018^{* * *}$ & $-0,064^{* * *}$ \\
\hline $\begin{array}{l}\text { Techniek excl. ICT \& } \\
\text { ambacht }\end{array}$ & $0,109^{* * *}$ & $0,067^{* * \star}$ & $-0.068^{\star * *}$ & $-0.061^{* * *}$ \\
\hline Technisch ambacht & $-0,087^{* * *}$ & $-0.148^{* * *}$ & $-0.279^{* * *}$ & $-0.255^{\star * *}$ \\
\hline Observaties & 527.913 & 530.588 & 419.740 & 162.682 \\
\hline R-kwadraat & 0,338 & 0,414 & 0,439 & 0,382 \\
\hline
\end{tabular}

${ }^{\$}$ Volgens de ROA-definitie.

Leeftijd, leeftijd ${ }^{2}$, geslacht, herkomst, jaar, en dummy parttime werk als controlevariabelen. Geen techniek beroep is de referentiecategorie.

- Op wo- en hbo-niveau is het loon van technici die een technisch beroep hebben lager dan voor technici die geen technisch beroep hebben.

- Op mbo-niveau is het loon voor technici hoger voor technische beroepen dan voor niet-technische beroepen, behalve voor technische ambachtsberoepen. 


\section{$6 \quad$ Andere studies}

\section{Bevindingen:}

- Werkgevers geven aan grote moeite te hebben om voldoende en geschikt personeel te vinden.

- Technische studenten vinden secundaire arbeidsvoorwaarden ook belangrijk.

Uit de voorgaande hoofdstukken blijkt dat een (aanzienlijk) gedeelte van de technici in Nederland werkzaam is in een niet-technisch beroep. Alhoewel technici aangeven dat zij vinden dat de aansluiting van de studie op de arbeidsmarkt beter is voor een technisch beroep, geeft een grote meerderheid van de technici met een niettechnisch beroep aan dat ook dit niet-technische beroep goed aansluit bij de studie. Dit geldt voornamelijk sterk voor hbo- en wo-opgeleide technici. In vergelijking met niet-technische beroepen, komt deeltijdwerken minder vaak voor bij technische beroepen en is het aandeel vrouwen relatief laag. Voor mbo-technici is het loon in technische beroepen beter dan in niet-technische beroepen, terwijl dit voor hbo- en wo-technici juist niet het geval is. Uit dit rapport kan niet opgemaakt worden hoe belangrijk deze baankenmerken van technische beroepen zijn voor de keuze van technici op de arbeidsmarkt. Uit verschillende recente studies van ROA kan wel een breder beeld geschetst worden van de arbeidsmarkt voor technici, zowel vanuit een werkgevers als werknemers perspectief.

In de jaarlijkse arbeidsmarktmonitor van de bedrijven die aangesloten zijn bij het pensioenfonds van de metaal- en elektrotechniek (metalektro) wordt veel aandacht besteed aan de krapte op de arbeidsmarkt. Werkgevers in de metalektro geven aan dat de belangrijkste oorzaken van wervingsproblemen voor technici in de afgelopen jaren ligt in te weinig sollicitanten, en in de kwaliteit van de sollicitanten, zoals blijkt uit figuur 6.1 (Dijksman et al. 2018). Voor werkgevers lijkt de aansluiting onderwijsarbeidsmarkt minder gunstig te zijn.

In het rapport wordt ook verwezen naar de arbeidsmarktpreferenties van technici. Daarbij blijkt de work-life balans belangrijker te worden, en is er een aantal kenmerken van technische beroepen, zoals het werken in ploegendiensten en het continue karakter van het beroep, die daar minder gunstig tegen af steken. Ook het deeltijdwerken zou beter gefaciliteerd moeten worden binnen de Metalektro om de sector aantrekkelijker te maken voor vrouwen (Dijksman et al. 2018, Gelderblom en De Hek 2014). 
Figuur 6.1 Belangrijkste oorzaken van de wervingsproblemen voor technici (\% bedrijven), 2013-2017

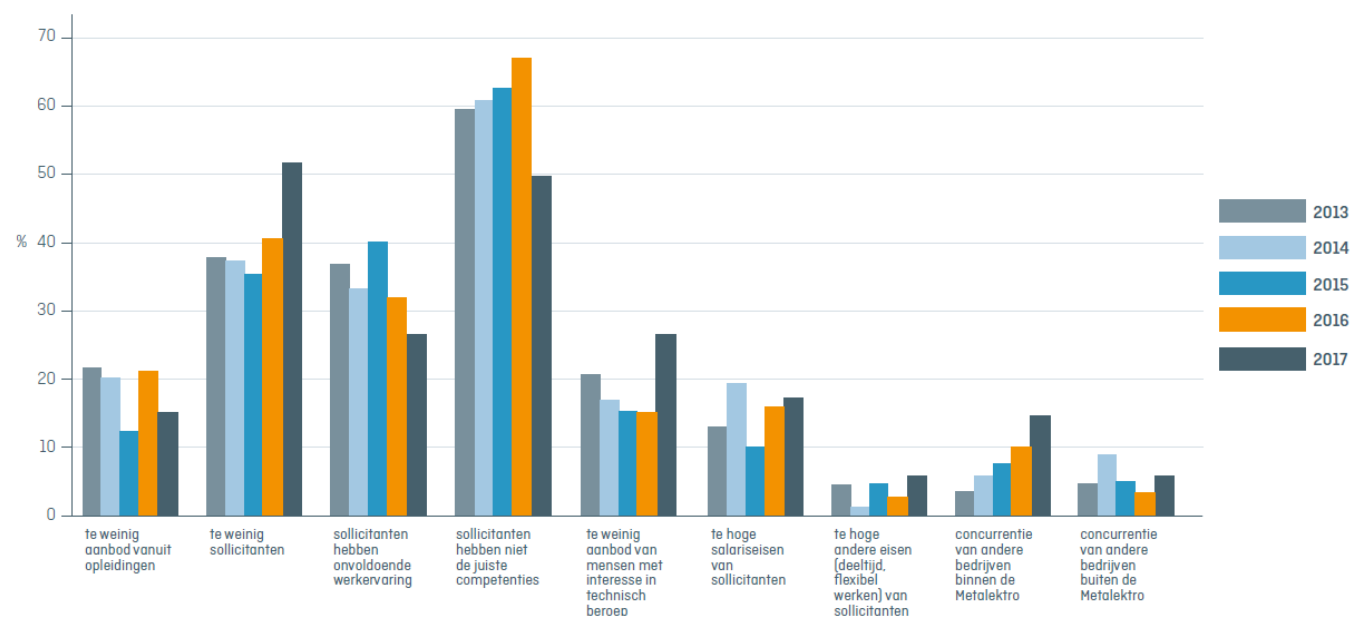

Bron: ROA, Arbeidsmarktmonitor Metalektro, 2013-2017

*In 2013 werd gevraagd naar de oorzaken van de wervingsproblemen in de afgelopen 6 maanden, terwij sinds 2014 wordt gevraagd naar de afgelopen 12 maanden.

Uit een enquête onder masterstudenten van de TU Delft en TU Eindhoven naar hun baan- en werkpreferenties, blijkt dat naast de work-life balans, ook het krijgen van een vast contract, autonomie in het werk, en werken in teamverband belangrijk zijn (Non et al. 2018). Daarnaast hecht deze groep ook steeds meer waarde aan de maatschappelijke taak van het bedrijf waarvoor ze werken en is er veel aandacht voor duurzaamheid.

De arbeidsmarkt keuze van technici wordt dus niet alleen gedreven door het loon. Veel secondaire arbeidsvoorwaarden en baankenmerken spelen een (steeds meer) belangrijke rol. Voor een vollediger beeld van de arbeidsmarktkeuze van technici, maar ook van de keuze van jongeren voor een technische studie, zijn andere studies beschikbaar. Inhoudelijke studies over onderwijs en arbeidsmarkt voor bèta-technici, o.a. over de aansluiting van technisch onderwijs in het mbo en wo, de keuze voor technische opleidingen in het voortgezet onderwijs, en de baankeuze van technici, zijn te vinden in Technotopics (De Grip en Marey 2006, De Grip en Smits 2008, en Fouarge en De Grip 2008). 


\section{Conclusie}

$\mathrm{Er}$ is sprake van een grote frictie tussen vraag en aanbod op de arbeidsmarkt voor technici, met grote knelpunten in de personeelsvoorziening als gevolg. Bovendien komt een grote groep technici niet terecht in een typisch technisch beroep en waaiert uit over verschillende niet-technische beroepen. Enerzijds laten de cijfers duidelijk zien dat niet-technisch opgeleide mensen bijna nooit in een technisch beroep werken, dus dat er specifieke kennis nodig is voor technische beroepen die voornamelijk geleerd wordt tijdens een technische studie. Aan de andere kant geven veel technici met een niet-technisch beroep aan dat hun studie ook redelijk goed tot goed aansluit bij hun huidige functie. Dit geeft aan dat technische vaardigheden ook steeds vaker van pas komen in niet-technische beroepen. Als de vraag naar technisch geschoolden voor niet-technische beroepen steeds groter wordt, is het de vraag of dit uiteindelijk wel gezien moet worden als een uitstroom van technici uit de technische sector en als mismatch tussen opleiding en arbeidsmarktpositie.

Technische beroepen wijken op een aantal punten sterk af van niet-technische beroepen. Zo zijn zowel de deeltijdfactor als het aandeel vrouwen relatief laag. Enerzijds kan de lage deeltijdfactor in technische beroepen duiden op een conservatieve werkkring, maar anderzijds zijn er veel technische beroepen waarvan de werkzaamheden dag en nacht doorgaan en er bijvoorbeeld in ploegendiensten gewerkt moet worden. In de metalektro-sector is een roep om meer mogelijkheden voor deeltijd werk om ook vrouwen te binden aan de sector. Het behouden van vrouwen met een technische opleiding voor een technisch beroep kan een oplossing zijn voor het capaciteitsprobleem van werkgevers in de techniek. Het tekort aan goed gekwalificeerd personeel op de arbeidsmarkt, zoals dat door werkgevers wordt aangegeven, moet op een andere manier worden opgelost.

Daarnaast blijkt dat het loon voor hbo- en wo-technici hoger is in niet-technische beroepen. Aangezien dit ook gevonden worden voor recent gediplomeerden, worden deze resultaten in ieder geval voor deze groep niet bepaald door het feit dat bepaalde niet-technische beroepen, zoals manager, een hoger loon hebben. Als personeel schaars is, dan stijgen de lonen. Dit kan een verklaring zijn voor de hogere Ionen van technici in niet-technische beroepen omdat technici daar schaarser zijn. Een andere verklaring is dat lonen in de techniek, door bijvoorbeeld cao's of internationale concurrentie en outsourcing, lager liggen dan in andere sectoren. Een andere verklaring voor het hogere loon van technici buiten de techniek kan zijn dat de beste technici hogere lonen kunnen onderhandelen en daardoor niet in de techniek terecht komen. In hoeverre het loonverschil tussen technische en niettechnische beroepen voor mensen met meer ervaring in stand blijt door de bovenstaande redenen, of dat ook de samenstelling van niet-technische beroepen een rol speelt (zoals managers die een hoger loon hebben), kan in vervolg onderzoek bekeken worden. 
Alhoewel het aannemelijk is dat het loon wel een rol speelt in de beroepskeuze van technici, laten recente studies zien dat andere baankenmerken, zoals autonomie, work-life balance, werken in teamverband en de maatschappelijke zingeving van de baan belangrijke aspecten zijn voor masterstudenten aan technische universiteiten.

Vervolgonderzoek naar de motivatie van technici om wel of niet voor een technisch beroep te kiezen is nodig voor beleidsaanbevelingen gericht op de mogelijkheden voor het behoud van technici voor de techniek. Daarnaast kan in onderzoek gekeken worden naar de studiekeuze van scholieren en welke aspecten een rol spelen bij het kiezen voor een technische of bètastudie om de instroom te vergroten.

Ook vanuit de werkgevers is meer informatie nodig over de aansluiting onderwijsarbeidsmarkt om beleidsaanbevelingen te kunnen doen om het tekort aan (gekwalificeerd) technisch personeel aan te pakken. Werkgevers geven nu aan dat zij problemen ondervinden om voldoende en goed gekwalificeerd technisch personeel te vinden. In vervolgonderzoek moet onderzocht worden waar de discrepanties liggen tussen de vaardigheden die werkgevers in de techniek eisen en de kennis en vaardigheden die in het curriculum van technische opleidingen worden aangeleerd. Daarnaast is het belangrijk om inzicht te krijgen in de manier waarop werkgevers tekorten oplossen, bijvoorbeeld door lagere opleidingseisen te stellen of door bedrijfsopleidingen te verzorgen voor nieuwe werknemers. Onder werkgevers in de niet-technische sector is het interessant om te onderzoeken waarom technisch geschoolden voor niet-technische beroepen geschikt zijn, en welke technische vaardigheden en technische kennis in niet-technische beroepen belangrijk is. 


\section{Verwijzingen}

Van den Berg, E., Van Eldert, P, Fouarge, F. en ter Weel, B. (2018). Taken en Vaardigheden op het werk. Maastricht: ROA-R-2018/6

Dijksman, S., Gerards, R., De Grip, A., Peeters, T., Van Eldert, P. en Veth, J. (2018). Jaarrapportage Arbeidsmarktmonitor Metalektro 2017, Stichting $\mathrm{A}+\mathrm{O}$ Metalektro, Hazerswoude-Dorp

Fouarge, D. en De Grip, A. reds. (2008). Technotopics III: Essays over Onderwijs en de Arbeidsmarkt voor Bètatechnici, ROA en Platform Bèta Techniek.

Fouarge, D. (2017). Veranderingen in Werk en Vaardigheden, Oratie, Maastricht University.

Gelderblom en de Hek (2014). Technisch opgeleid: wel of niet werken in de techniek? eindrapport in opdracht van techniektalent.nu. SEOR

De Grip, A. en Marey, P. reds. (2006). Technotopics: Essays over Onderwijs en de Arbeidsmarkt voor Bètatechnici, ROA en Platform Bèta Techniek.

De Grip, A. en Smits, W. reds. (2008). Technotopics II: Essays over Onderwijs en de Arbeidsmarkt voor Bètatechnici, ROA en Platform Bèta Techniek.

Non, A., Rohde, I., De Grip, A. en Dohmen, T. (2018). Mission of the Company, Prosocial attitudes and Jobs Preferences: a Stated-Preference Experiment, ROA (verschijnt binnenkort).

ROA/CBS (2015), Beroepenindeling ROA-CBS 2014 (BRC 2014), Maastricht: ROATR-2015/5.

ROA, 2017a. De Arbeidsmarkt naar Opleiding en Beroep tot 2022, ROA-R-2017/10, http://roa.sbe.maastrichtuniversity.nl/roanew/wpcontent/uploads/2018/01/ROA R 2017 10.pdf

ROA 2017b. Schoolverlaters tussen Onderwijs en Arbeidsmarkt, ROA-R-2017/7, http://roa.sbe.maastrichtuniversity.nl/roanew/wpcontent/uploads/2014/02/ROA R 2017 7.pdf

SEO 2015. Weglek van Bètatechnisch Potentieel, SEO-Discussion paper nr. 81, http://www.seo.nl/uploads/media/DP81 Weglek van betatechnisch potentieel.pdf 


\title{
Bijlage I ROA beroepenclassificatie
}

\author{
Beroepsklassen, beroepssegment en onderliggende beroepsgroepen ${ }^{1}$

Beroepsklasse Beroepssegment Beroepsgroep \\ Pedagogische beroepen \\ Docenten \\ Docenten hoger onderwijs en \\ hoogleraren \\ Docenten beroepsgerichte vakken \\ secundair onderwijs \\ Docenten algemene vakken secundair \\ onderwijs \\ Leerkrachten basisonderwijs \\ Onderwijskundigen en overige docenten \\ Sportinstructeurs \\ Sportinstructeurs \\ Leidsters kinderopvang en onderwijsassistenten \\ Leidsters kinderopvang en \\ onderwijsassistenten \\ Creatieve en taalkundige beroepen \\ Auteurs en kunstenaars \\ Bibliothecarissen en conservatoren \\ Auteurs en taalkundigen \\ Journalisten \\ Beeldend kunstenaars \\ Uitvoerend kunstenaars \\ Vakspecialisten op artistiek en cultureel gebied \\ Grafisch vormgevers en \\ productontwerpers \\ Fotografen en interieurontwerpers \\ Commerciële beroepen \\ Adviseurs marketing, public relations en sales \\ Adviseurs marketing, public relations en \\ sales \\ Vertegenwoordigers en inkopers \\ Vertegenwoordigers en inkopers \\ Verkopers \\ Winkeliers en teamleiders detailhandel
}

1. Zie: ROA/CBS (2015). Beroepenindeling ROA-CBS 2014 (BRC 2014). Maastricht: ROA-TR$2015 / 5$. 
Verkoopmedewerkers detailhandel

Kassamedewerkers

Callcentermedewerkers outbound en overige verkopers

Bedrijfseconomische en administratieve beroepen

Specialisten bedrijfsbeheer en administratie

Accountants

Financieel specialisten en economen

Bedrijfskundigen en organisatieadviseurs

Beleidsadviseurs

Specialisten personeels- en

loopbaanontwikkeling

Vakspecialisten bedrijfsbeheer en administratie

Boekhouders

Zakelijke dienstverleners

Directiesecretaresses

Administratief personeel

Administratief medewerkers

Secretaresses

Receptionisten en telefonisten

Boekhoudkundig medewerkers

Transportplanners en logistiek

medewerkers

Managers

Algemeen directeuren

Algemeen directeuren

Managers op administratief en commercieel gebied Managers zakelijke en administratieve dienstverlening

Managers verkoop en marketing

Managers productie en gespecialiseerde dienstverlening

Managers productie

Managers logistiek

Managers ICT

Managers zorginstellingen

Managers onderwijs

Managers gespecialiseerde

dienstverlening

Managers horeca, detailhandel en overige diensten

Managers horeca

Managers detail- en groothandel 
Managers commerciële en persoonlijke dienstverlening

Managers z.n.d.

Managers z.n.d.

Openbaar bestuur, veiligheid en juridische beroepen

Overheidsambtenaren en -bestuurders

Overheidsbestuurders

Overheidsambtenaren

Juristen

Juristen

Beveiligingswerkers

Politie-inspecteurs

Politie en brandweer

Beveiligingspersoneel

Militaire beroepen

Technische beroepen

Ingenieurs en onderzoekers wis-, natuur- en technische wetenschappen

Biologen en natuurwetenschappers

Ingenieurs (geen elektrotechniek)

Elektrotechnisch ingenieurs

Architecten

Vakspecialisten natuur en techniek

Technici bouwkunde en natuur

Productieleiders industrie en bouw

Procesoperators

Bouwarbeiders

Bouwarbeiders ruwbouw

Timmerlieden

Bouwarbeiders afbouw

Loodgieters en pijpfitters

Schilders en metaalspuiters

Metaalarbeiders, machinemonteurs

Metaalbewerkers en constructiewerkers

Lassers en plaatwerkers

Automonteurs

Machinemonteurs

Voedselverwerkende beroepen en overige ambachten

Slagers

Bakkers 
Productcontroleurs

Meubelmakers, kleermakers en

stoffeerders

Medewerkers drukkerij en kunstnijverheid

Elektriciens en elektronicamonteurs

Elektriciens en elektronicamonteurs

Productiemachinebedieners en assemblagemedewerkers

Productiemachinebedieners

Assemblagemedewerkers

Hulpkrachten bouw en industrie

Hulpkrachten bouw en industrie

ICT-beroepen

Specialisten ICT

Software- en applicatieontwikkelaars

Databank- en netwerkspecialisten

Vakspecialisten ICT

Gebruikersondersteuning ICT

Radio- en televisietechnici

Agrarische beroepen

Tuinders, akkerbouwers en veetelers

Land- en bosbouwers

Hoveniers, tuinders en kwekers

Veetelers

Hulpkrachten landbouw

Hulpkrachten landbouw

Zorg- en welzijnberoepen

Artsen, therapeuten en gespecialiseerd verpleegkundigen

Artsen

Gespecialiseerd verpleegkundigen

Fysiotherapeuten

Specialisten op maatschappelijk gebied

Maatschappelijk werkers

Psychologen en sociologen

Vakspecialisten gezondheidszorg

Laboranten

Apothekersassistenten

Verpleegkundigen (mbo)

Medisch praktijkassistenten

Medisch vakspecialisten 
Sociaal werkers, groeps- en woonbegeleiders

Sociaal werkers, groeps- en woonbegeleiders

Verzorgenden

Verzorgenden

Dienstverlenende beroepen

Medewerkers persoonlijke dienstverlening

Reisbegeleiders

Koks

Kelners en barpersoneel

Kappers en schoonheidsspecialisten

Conciërges en teamleiders schoonmaak Verleners van overige persoonlijke diensten

Schoonmakers en keukenhulpen

Schoonmakers

Keukenhulpen

Transport- enlogistiek beroepen

Bestuurders voertuigen en bedieners mobiele machines

Dekofficieren en piloten

Chauffeurs auto's, taxi's en bestelwagens

Buschauffeurs en trambestuurders

Vrachtwagenchauffeurs

Bedieners mobiele machines

Hulpkrachten transport en logistiek

Laders, lossers en vakkenvullers

Vuilnisophalers en dagbladenbezorgers

Overig

Overig

Overig 


\section{Bijlage II ROA opleidingsclassificatie}

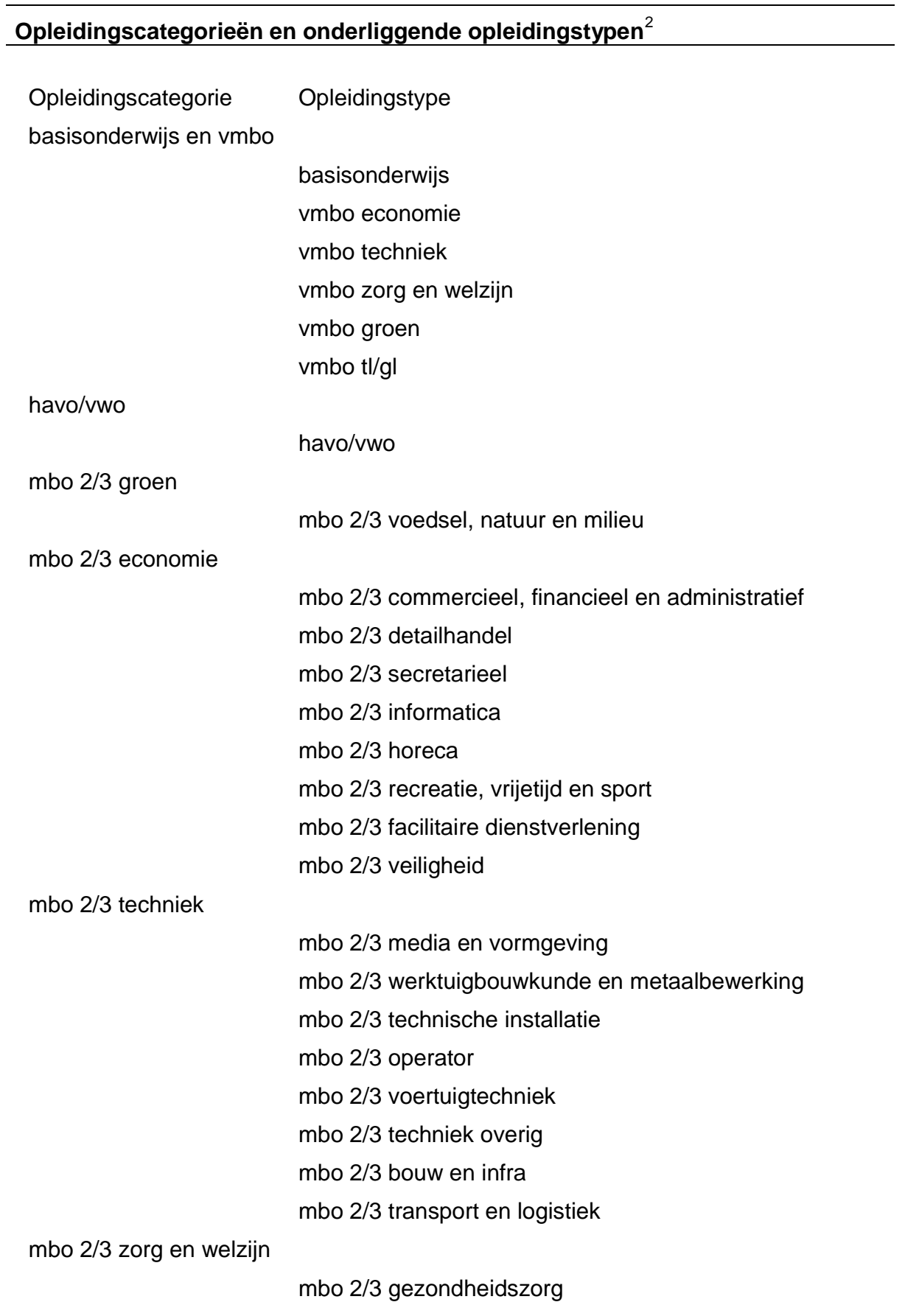

2. Zie: ROA (2016). ROA opleidingsindeling 2015. Maastricht: ROA-TR-2016/3. 
mbo 2/3 maatschappelijke zorg

mbo 2/3 schoonheids- en haarverzorging

mbo 4 groen

mbo 4 voedsel, natuur en milieu

mbo 4 economie

mbo 4 commercieel, financieel en administratief

mbo 4 detailhandel

mbo 4 secretarieel

mbo 4 informatica

mbo 4 horeca

mbo 4 recreatie, vrijetijd en sport

mbo 4 facilitaire dienstverlening

mbo 4 techniek

mbo 4 media en vormgeving

mbo 4 werktuigbouwkunde en metaalbewerking

mbo 4 technische installatie

mbo 4 operator

mbo 4 voertuigtechniek

mbo 4 techniek overig

mbo 4 bouw en infra

mbo 4 transport en logistiek

mbo 4 zorg en welzijn

mbo 4 onderwijs

mbo 4 gezondheidszorg

mbo 4 maatschappelijke zorg

mbo 4 schoonheids- en haarverzorging

hbo onderwijs

hbo leraar basisonderwijs

hbo leraar algemene vakken

hbo leraar beroepsgerichte vakken

hbo taal en cultuur

hbo kunst

hbo communicatie

hbo journalistiek

hbo economie

hbo bedrijfseconomie

hbo marketing en commerciele economie

hbo accountancy en financiën 
hbo bedrijfskunde en hrm

hbo recht

hbo hotel, vrijetijd en facility management

hbo techniek

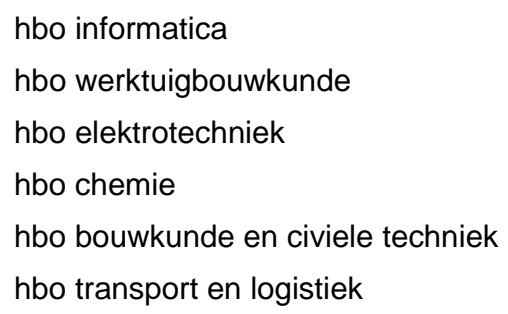

hbo landbouw en natuur

hbo natuur en milieu

hbo landbouw

hbo gezondheidszorg

hbo verpleegkunde en medische diagnostiek hbo fysiotherapie

hbo gedrag en maatschappij

hbo pedagogiek

hbo sociaal cultureel

hbo maatschappelijk werk

wo onderwijs

wo onderwijs

wo taal en cultuur

wo kunst

wo taal, cultuur en journalistiek

wo communicatie

wo economie en recht

wo economie

wo bedrijfseconomie en logistiek

wo accountancy en financiën

wo bedrijfskunde en hrm

wo recht

wo techniek

wo informatica

wo werktuigbouwkunde en elektrotechniek

wo bouwkunde en civiele techniek

wo landbouw en natuur

wo biologie, wiskunde, landbouw en milieu 
wo natuur- en scheikunde

wo medisch

wo (dier)geneeskunde en tandheelkunde

wo gezondheidszorg

wo gedrag en maatschappij

wo politicologie en sociologie

wo psychologie en maatschappelijk werk

Overig

Overig 